\title{
Article \\ Influence of Cairo Metro Tunnel Excavation on Pile Deep Foundation of the Adjacent Underground Structures: Numerical Study
}

\author{
Mo'men Ayasrah ${ }^{1, *}$, Hongsheng Qiu ${ }^{2}$ and Xiedong Zhang ${ }^{2}$ \\ 1 Communication and Transportation Engineering, School of Transportation, Wuhan University of Technology, \\ Wuhan 430063, China \\ 2 Road and Railway Engineering, School of Transportation, Wuhan University of Technology, \\ Wuhan 430063, China; 2755@whut.edu.cn (H.Q.); zhangxd@whut.edu.cn (X.Z.) \\ * Correspondence: ayasrahmomen@whut.edu.cn; Tel.: +86-15623766037
}

Citation: Ayasrah, M.; Qiu, H.; Zhang, X. Influence of Cairo Metro Tunnel Excavation on Pile Deep Foundation of the Adjacent Underground Structures: Numerical Study. Symmetry 2021, 13, 426. https://doi.org/10.3390/sym13030426

Academic Editor: Igor V. Andrianov

Received: 6 February 2021

Accepted: 3 March 2021

Published: 6 March 2021

Publisher's Note: MDPI stays neutral with regard to jurisdictional claims in published maps and institutional affiliations.

Copyright: (c) 2021 by the authors. Licensee MDPI, Basel, Switzerland. This article is an open access article distributed under the terms and conditions of the Creative Commons Attribution (CC BY) license (https:// creativecommons.org/licenses/by/ $4.0 /)$.

\begin{abstract}
Day by day the call to solve traffic congestion problems is increasing. Subway tunnels and high-speed railway are commonly used for transportation. Therefore, tunnel construction induces soil movement, which in turn affects the stability and integrity of adjacent existing buildings. A series of numerical simulations have been established to investigate the effects of tunnel construction of the Greater Cairo Metro-Line 3-Phase-1 on adjacent pile cap foundations of Garage El-Attaba building. Many parameters have been investigated such as tunnel diameter and the distance between pile and tunnel at different tunnel axis and deep and shallow tunnel. After thorough analysis of the results' simulation, it was found that the tunneling induces additional axial forces and bending moment as well as increasing axial settlement and lateral deflection. Moreover, the results obtained from the parametric study for the shallow and deep tunnel show that the tunnel depth has a much significant effect on piles responses. Finally, the tunnel diameter has an impact on pile responses as well as the pile cap foundation influenced by the tunnel when the tunnel is in very close vicinity of the pile, and its effect is modest to negligible if located far away from the buildings.
\end{abstract}

Keywords: tunnel construction; soil movement; numerical simulations; bending moment; lateral deflection; shallow tunnel; deep tunnel

\section{Introduction}

In the light of the fast-urban developments in major cities, the demand for underground public facilities is vastly increasing. In recent years, the construction of tunnels has been relied on solving traffic congestion problems in many cities of the world. Pile foundation is commonly used in high-rise buildings to transmit the upper load to the subsurface. During the tunnel construction, many considerations must be taken especially tunneling effects on neighboring buildings with deep foundations [1-7].

It is well-acknowledged that the ground deformation occurring during the tunnel construction process relative to existing piles plays a significant role. Ground deformation affects the performance and the stability of piles, which in turn changes piles behavior. These changes induce additional axial settlements and lateral deflections as well as additional axial forces and bending moments. Consequently, it may lead to structural distress or failure of foundations and subsequently damage of the super-structure [2,8-17]. Based on the relative length of the pile compared to the depth of the tunnel, two main categories can be made: the deep tunnel "short pile" where the tunnel axis is located below the tip of the existing piles, $(\mathrm{Lp} / \mathrm{H}<1)$, while the second one is the shallow tunnel "long pile" where the tunnel axis is located above the tip of the existing pile, $(\mathrm{Lp} / \mathrm{H}>1)$ [18-20].

In the past decades, there has been a growing interest to understand the simple and reliable predictions of the tunneling effect on adjacent structures and soil movements 
around the tunnel. However, several authors [21-24] have proposed an empirical relationship between tunneling effects and associated structural damage based on the analysis of previous case studies. In addition, simple physical tests were built in laboratories, such as centrifuge model tests, and based on the results from analysis, design guidance for practical engineering constructions can be provided [8,25-27].

On the other hand, several studies based on numerical modeling, especially the finite element method, have been presented to simulate tunnel excavation. In addition, numerical simulation of any geotechnical problem depends mainly on the accuracy of the constitutive model used to simulate the stress-strain relationship of the soil. There are many constitutive soil models that have been developed based on the different purposes and concepts [28,29]. According to the full 3D FEM, modeling analysis conducted by [30] carried out a 3D finite element model to study the effects of tunneling on the adjacent piled structures using modified Mohr-Coulomb. The results showed that some critical responses reach maximum worth during tunneling, and it is not necessary to take place at the end of tunneling. In addition, the soil settlement was reduced; however, the increasing pile axial loads raise the risk on the piled structure. Moreover, the decrement in soil settlement indicated that the piles which extended deeper than the tunnel actually supported the soil above the tunnel.

Meanwhile, Lee and Jacobsz [31] conducted 3D elastic-plastic numerical for tunnelpile interactions. It was found that when a pile is located within 0-0.6 and 1.2-2.4 times the tunnel diameter, the surface settlement may not follow the normal settlement distributions. Therefore, they suggested, for safety, the position of piles should be at least one time the tunnel diameter measured laterally from the tunnel's crown to preserve the serviceability of the piled foundations. In addition, [32] executed out three-dimensional finite element analyses to investigate the shear stress transfer mechanism of single piles during tunneling in weathered residual soil. The results showed that the shear stress of the upper part of the pile is large, while the bottom is small in the tunneling process. It was also determined, relating to the pile position, that the majority of the axial force on the pile was evolving within \pm 2 times the diameter of the tunnel behind and ahead of the piles.

Jongpradist et al. [18] numerically conducted a three-dimensional simulation to investigate the effects of tunneling on adjacent pile foundations. It was found that when the pile tip was located within +3 to -1 times, the tunnel diameter from the tunnel horizontal axis, a considerable settlement occurred at the pile head. Moreover, the impact of the region had the $60^{\circ}$ inclination with respect to the horizontal direction.

Hence, it can be concluded that most of the studies were ultimately related to study the effect of the tunnel construction on piles and pile groups. However, the main purpose of the present study is to investigate the influence of tunneling progress (remove of soil elements and install of the lining) adjacent to existing pile cap foundations. In view of that, a three-dimensional model using a Modified Mohr-Coulomb constitutive model for the soil layers was established for this objective.

In this paper, the Greater Cairo Metro-Line 3-Phase-1 adjacent to Garage El-Attaba building pile cap foundations is taken as a case study. Furthermore, different factors have been studied with two different tunnel axes; deep and shallow tunnel on the response of pile cap foundation, among which tunnel diameter and the distance between pile and tunnel, to provide a better understanding of the behavior of pile responses influenced by tunneling.

The remainder of this paper is structured as follows. In Section 2, the details of the case study and soil conditions are presented. The Finite Element Modeling including numerical modeling, constitutive models and material parameters, and tunnel construction stage are discussed in Section 3. In Section 4, verification of the numerical model is investigated. Numerical results and discussion including the various factors are discussed in Section 5. Finally, conclusions are drawn in Section 6. 


\section{Case Study}

\subsection{Greater Cairo Metro-Line 3 Phase-1}

The Greater Cairo Underground Metro project is one of the Egyptian mega projects created to solve many traffic problems that have been recently elevated. Cairo Metro network connects the capital provinces with the center of the city through three lines, line 1 , line 2, and line 3. The Greater Cairo Metro-Line 3 was constructed by a slurry shield Tunnel Boring Machine (TBM), with a $9.55 \mathrm{~m}$ diameter. The tunnel has external and internal diameters of 9.15 and $8.35 \mathrm{~m}$, respectively. The precast segmental lining thickness is $0.4 \mathrm{~m}$. This line is $47.87 \mathrm{~km}$ in length, starting from Imbaba to Cairo airport; also, as planned, it is going to be constructed in four phases. In this study, The Greater Cairo Metro, Line 3, Phase-1 moves underground from El-Attaba to El-Abbasia stations and was considered to show the tunneling effect on Garage El-Attaba building foundation. This Phase is $4.3 \mathrm{~km}$ in length and consists of 5 underground stations and 4 annexed structures, as shown in Figure 1 .

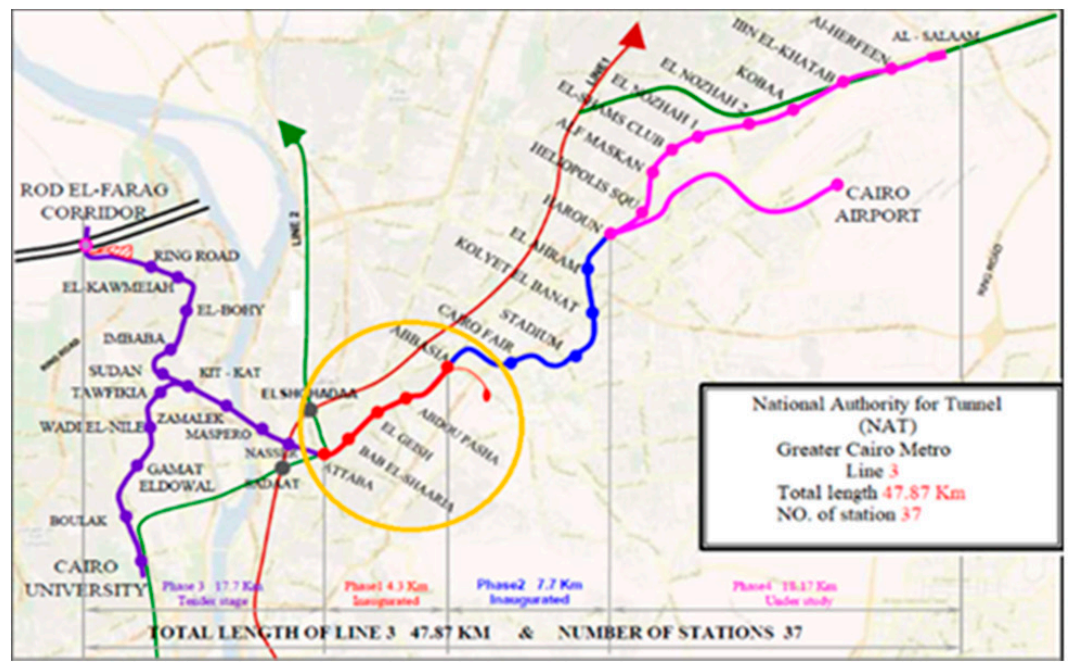

(a)

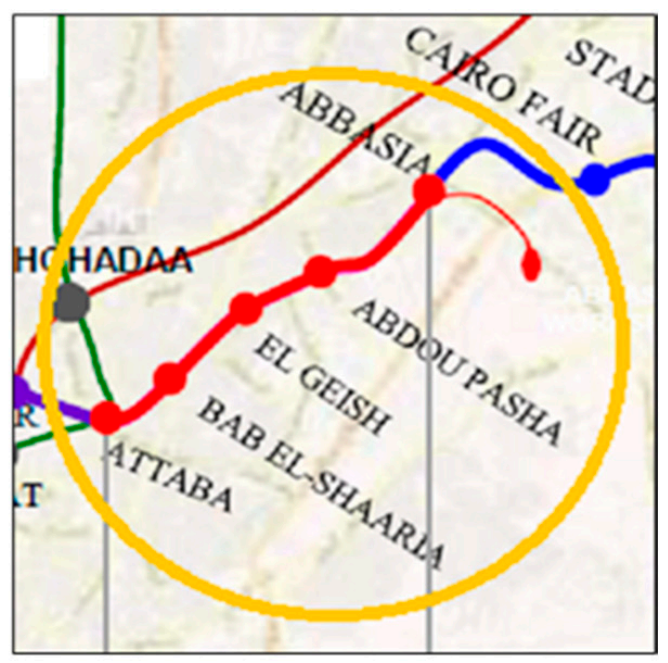

(b)

Figure 1. (a) The Greater Cairo Metro-Line 3, after National Authority for Tunneling; (b) zone of the study [33].

Garage El-Attaba building is $77.04 \mathrm{~m}$ in length and $45.55 \mathrm{~m}$ in width. It is founded nearby the Greater Cairo Metro-Line 3-phase-1, built with eight stories as shown in Figure 2. This building is about $6.45 \mathrm{~m}$ from the center of the tunnel and making an angle of about $42^{\circ}$ from the tunnel as shown in Figure 3. This building was supported by 245 nondisplacement concrete piles arranged in the pile caps group. The pile dimensions are $0.6 \mathrm{~m}$ in diameter and $20 \mathrm{~m}$ in length and passes through layered soil. The design allowable load capacity for the pile is $1200 \mathrm{kN}$ [34]. Fundamental to note that only the four piles caps (PC1, PC2, PC3, and PC4) that are the nearest to the tunnel are assigned in this study. Figure 4 shows the pile caps details and the pile cap and pile tip location to tunnel axis. 


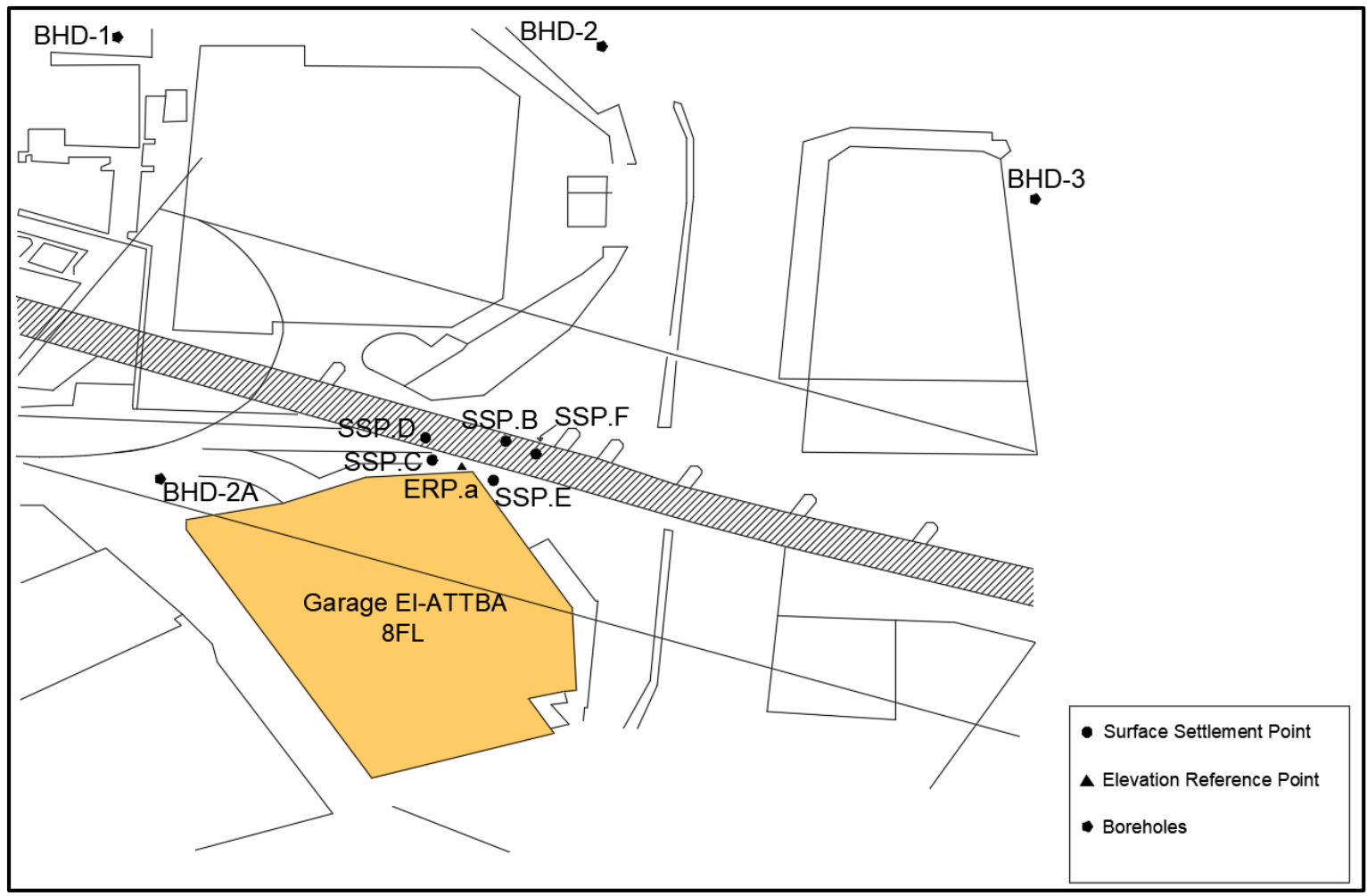

Figure 2. Location of Garage El-Attaba according to Greater Cairo Metro and instruments system layout [33,35].

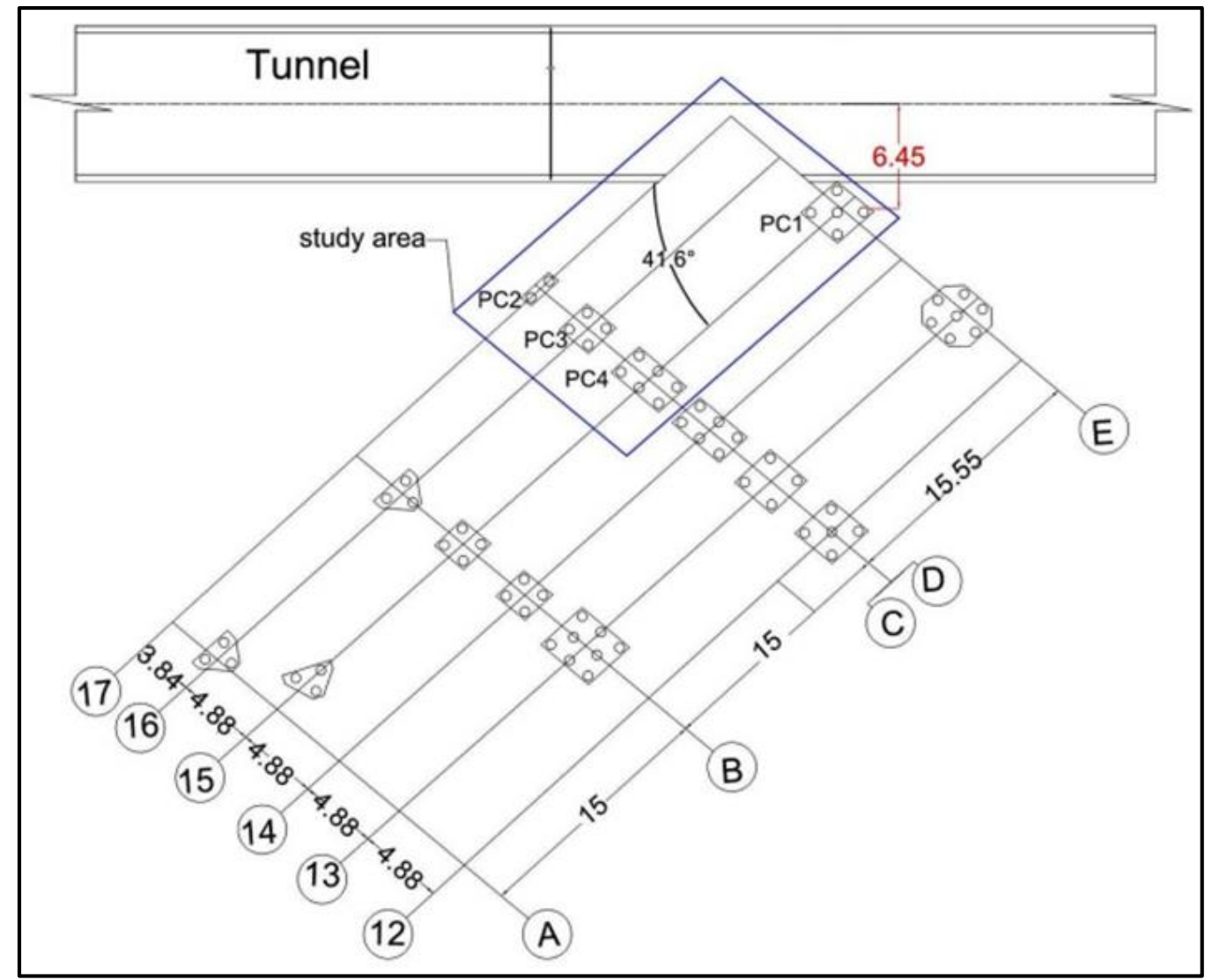

Figure 3. The pile caps position relative to the tunnel route. Units in (m). 


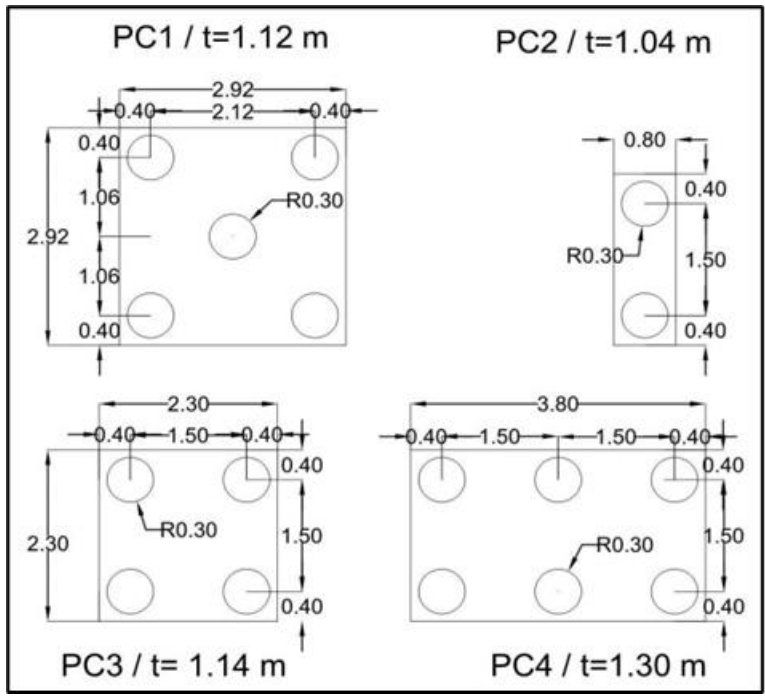

(a)

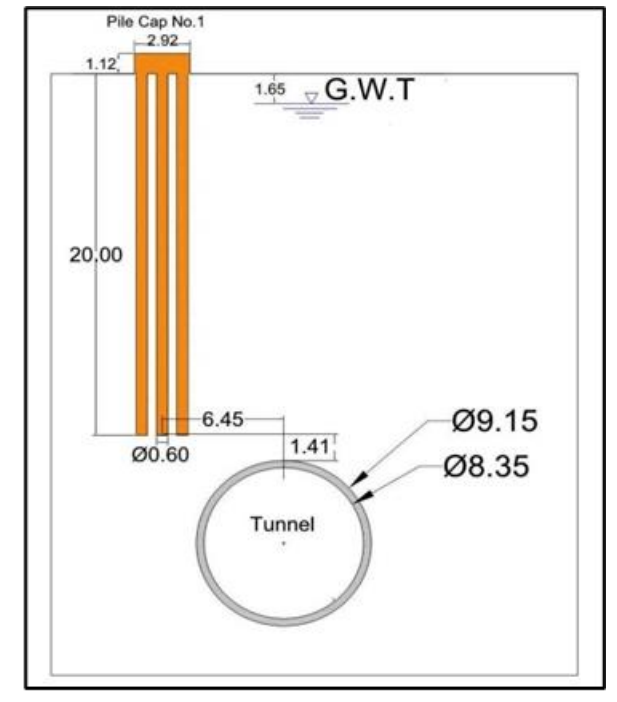

(b)

Figure 4. (a) The pile caps details and (b) pile cap and pile tip location to tunnel axis. Units in (m) [34].

\subsection{Soil Conditions}

Geotechnical investigation of the Greater Cairo Metro, Line 3, Phase-1 included the drilling of thirteen boreholes and standard penetration tests [35]. As shown in Figure 2, borehole No. 2A is nearest to the Garage El-Attaba building. Therefore, the soil crosssection at this borehole was taken as representative of the soil profile in this study. The description of the soil layers is presented from the study by [36] which used field and laboratory tests for determining the soil properties as shown in Figure 5. The groundwater existed at an average depth of $1.65 \mathrm{~m}$ below the ground surface.

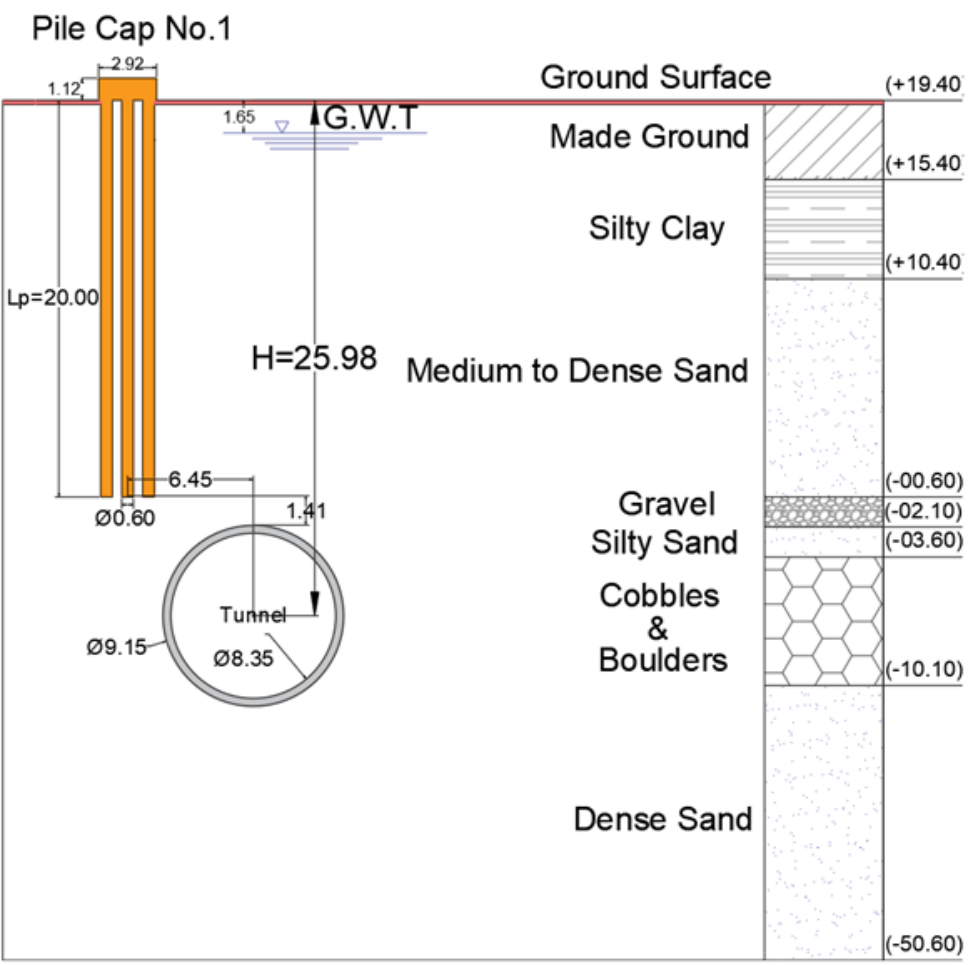

Figure 5. Soil profile at the location of BHD. 2A [35]. 


\section{Finite Element Modelling}

\subsection{Numerical Model}

According to the overview of the Greater Cairo Metro Line 3-phase-1 project, there is the Garage El-Attaba building near the construction line. A three-dimensional model is established to study the effect of excavation and tunnel construction of Cairo Metro on the foundations of adjacent Garage El-Attaba building using Midas GTS-NX finite element package. Considering the influence of boundary effects on the accuracy of the numerical results, the area with the most risk of construction was chosen to establish a 3D finite element model to investigate the influence of tunnel construction on 17 adjacent pile groups. In this study, a perspective view of the numerical model is shown in Figure 6. The mesh applied in this model consisted of 51,838 nodes and 300,647 elements. The mesh size is extended in $108 \mathrm{~m}$ (length), $108 \mathrm{~m}$ (width), and $55 \mathrm{~m}$ (depth) in $\mathrm{X}, \mathrm{Y}$, and $\mathrm{Z}$ directions, respectively, as shown in Figure 6. These dimensions were sufficiently large to minimize boundary effects in the numerical modeling because the larger increase in mesh size did not lead to any change in the analysis results. The ground soil, piles, pile caps, and tunnel lining were simulated using tetrahedron elements. The shield was simulated as a plate and the interface element is not prescribed between the pile and the soil.

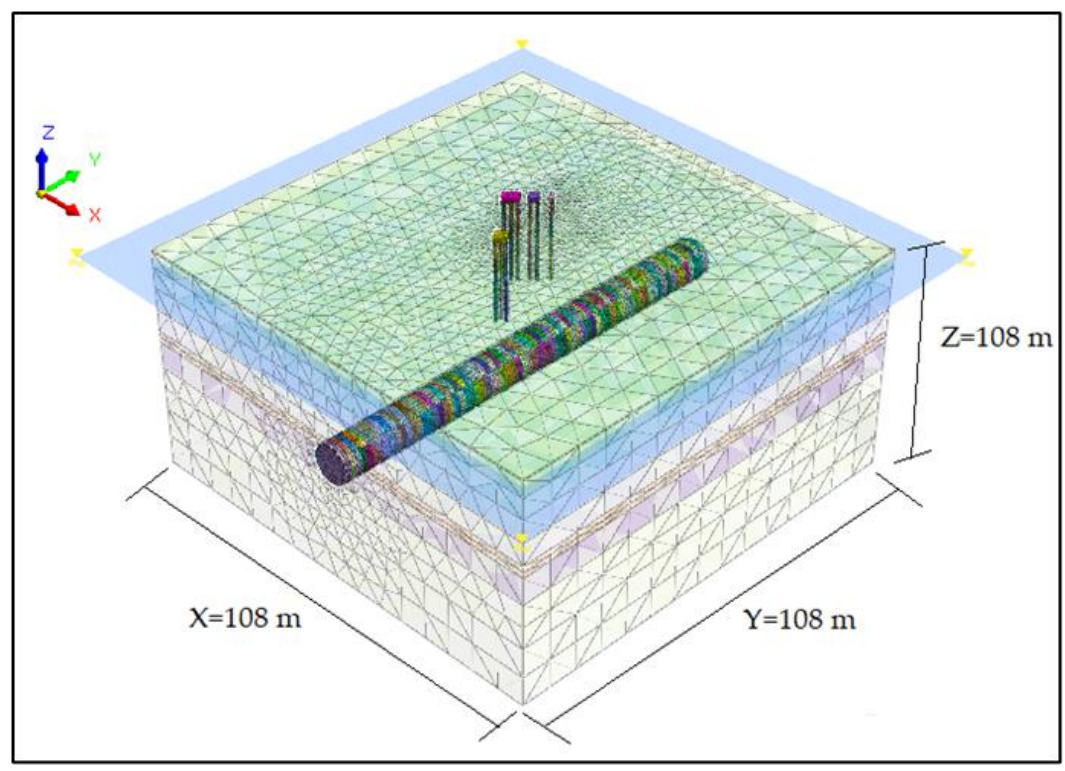

Figure 6. 3D finite element model.

In this model, ground soil, tunnel lining, piles, and pile caps were simulated as continuum solids, while the shield machine was considered as a continuum shell. The boundary conditions were assumed to be pinned at the end of the lower soil to prevent any movement in any direction, and a roller was applied in the side of the model to allow a movement in the vertical direction. A relatively fine mesh was used near the tunnel and piles location due to the intensification of wide shear strains; while further away from outside these zones, the coarser mesh was used.

\subsection{Constitutive Models and Material Parameters}

Many factors impact the performance and the results accuracy of the numerical simulation such as the constitutive model and calculation parameters. The Modified Mohr-Coulomb successfully employed in simulation the behavior of various types of soils, both soft and stiff soils [37-39]. In addition, The Modified Mohr-Coulomb formulation incorporates two hardening mechanisms, shear and density hardening. In the case of the tunneling construction progress, the loading and unloading behavior of soil must be 
simulated [40-45]. Therefore, in this study, the constitutive behavior of soil layers was modeled as a Modified Mohr-Coulomb model.

Furthermore, the Modified Mohr-Coulomb constitutive model is described more accurately because it takes into account three different soil stiffness parameters, which correspond to three loading conditions, namely, triaxial loading stiffness, oedometer loading stiffness, and unloading-reloading modulus. For every stress increment, if the soil exposes undergoing primary loading, there is a corresponding incremental elastic and plastic strain. Otherwise, if the soil is exposed to unloading-reloading, there is an elastic strain only [46].

Based on the geotechnical investigations' report [35], the physical characteristics of the soil strata (Figure 5) are summarized in Table 1. For the clay layer, undrained shear strength $\left(q_{u}\right)$ of $222 \mathrm{kN} / \mathrm{m}^{2}$ was determined using the unconfined compression test. Therefore, the undrained cohesion $\left(C_{u}\right)$ is taken as $111 \mathrm{kN} / \mathrm{m}^{2}$ in this analysis. Moreover, the undrained Young's modulus $\left(E_{u}\right)$ of the cohesive soil layer is estimated using Equation (1).

$$
E_{u}=k C_{u}
$$

where $k$ is evaluated using Duncan chart (Duncan, (1976)) [47].

Table 1. Soil layers engineering parameters.

\begin{tabular}{|c|c|c|c|c|c|c|c|}
\hline${ }_{\text {Parameter }}$ Soil Layers & $\begin{array}{l}\text { Made } \\
\text { Ground }\end{array}$ & $\begin{array}{l}\text { Silty } \\
\text { Clay }\end{array}$ & Upper Sand & Gravel & $\begin{array}{l}\text { Middle } \\
\text { Sand }\end{array}$ & $\begin{array}{l}\text { Cobbles and } \\
\text { Boulders }\end{array}$ & Lower Sand \\
\hline Thick. (m) & 4.00 & 5.00 & 11.00 & 1.50 & 1.50 & 6.50 & Extended \\
\hline Unit weight $\left(\mathrm{kN} / \mathrm{m}^{3}\right)$ & 17 & 17.67 & 19.5 & 20 & 19.5 & 21 & 19.5 \\
\hline Friction angle $\left({ }^{\circ}\right)$ & 27 & $\varphi_{\mathrm{u}}=0$ & 36 & 36 & 35 & 36 & 34 \\
\hline Cohesion $(\mathrm{kPa})$ & 0 & $C_{u}=111$ & 0 & 0 & 0 & 0 & 0 \\
\hline $\begin{array}{l}\text { Lateral earth pressure } \\
\text { coefficient (-) }\end{array}$ & 0.546 & 1 & 0.412 & 0.384 & 0.384 & 0.412 & 0.384 \\
\hline Poisson's ratio (-) & 0.3 & $v_{u}=0.3$ & 0.3 & 0.3 & 0.3 & 0.3 & 0.3 \\
\hline Dilatancy angle $\left(^{\circ}\right)$ & 0 & 0 & 6 & 6 & 5 & 6 & 4 \\
\hline $\begin{array}{l}\text { Triaxial loading stiffness } E_{50} \\
(\mathrm{MPa})\end{array}$ & 4 & 27.75 & 15.33 & 100 & 16.48 & 19.61 & 19.61 \\
\hline $\begin{array}{l}\text { Oedometer loading stiffness } \\
E_{\text {oed }}(\mathrm{MPa})\end{array}$ & 4 & 27.75 & 15.33 & 100 & 16.48 & 19.61 & 19.61 \\
\hline $\begin{array}{l}\text { Triaxial unloading stiffness } \\
E_{u r}(\mathrm{MPa})\end{array}$ & 12 & 83.25 & 45.98 & 300 & 49.43 & 58.84 & 58.84 \\
\hline
\end{tabular}

Additionally, for the sandy soil layers, the secant modulus of elasticity $\left(E_{50}\right)$ is estimated using the SPT original ( $N$-values) according to the Egyptian code of practice, ECP (202/3 (2005)) [48].

In most cases, $\left(E_{u r}\right)$ is set to three times $\left(E_{50}\right)$, and $\left(E_{\text {oed }}\right)$ is taken to be equal to $\left(E_{50}\right)$ [46]. For soil layers, dilatancy angle $(\psi)$ typically equal to be zero for undrained analysis and $\left(\psi=\varphi-30^{\circ}\right)$ for drained analysis [49]. According to the geological conditions at the site location, the over-consolidation ratio (OCR) was estimated to be equal to 1.0. In addition, the coefficient of lateral earth pressure at rest $\left(k_{o}\right)$ is estimated by Mayne and Kulhawy (1982) [50] using Equation (2).

$$
k_{\mathrm{o}}=(1-\sin \varphi) O C R^{\sin \varphi}
$$

On the other hand, a linear elastic model was used to simulate the piles, pile caps, tunnel lining, and shield machine. This model requires the input of two main parameters, i.e., Young's modulus $(E)$ and Poisson's ratio $(v)$ to describe the stress-strain relationship. Structural properties adopted in the numerical analysis are taken as given in Table 2. 
Table 2. Structural properties adopted in the numerical analysis.

\begin{tabular}{llllll}
\hline Parameters & Pile & Pile Cap & Lining & Shield & Grouting \\
\hline Elasticity modulus $(\mathrm{MPa})$ & $3.45 \times 10^{4}$ & $1.4 \times 10^{4}$ & $1.4 \times 10^{4}$ & $2 \times 10^{4}$ & $2 \times 10^{4}$ \\
Unit weight $\left(\mathrm{kN} / \mathrm{m}^{3}\right)$ & 25 & 25 & 25 & 78 & 22.5 \\
Possion's ratio $(-)$ & 0.15 & 0.15 & 0.15 & 0.3 & 0.3 \\
\hline
\end{tabular}

\subsection{Numerical Analysis Procedure}

The same material properties of the soil layers and structural elements listed in Tables 1 and 2, respectively, were employed in three-dimensional models. The shield tunnel lining construction consists of connecting a series of concrete ring segments, of about $1.5 \mathrm{~m}$ long for each segment (two segments of $1.5 \mathrm{~m}$ are erected in one calculation stage). In order to more realistically reflect the situation of shield excavation, the model sets the drilling pressure applied on the shield excavation face; jack thrust is applied in front of the segment face; shield external pressure and segment external pressure are applied around the tunnel. A 3D model's analysis was performed on the 46 stages including the initial stage. The following modeling sequence is followed:

1. The initial stage set up the initial stress and boundary conditions at-rest earth pressure coefficient of 0.5 .

2. The first stage starts with changing the properties of the piles to concrete material as soil material replacement. At this stage, the caps are activated.

3. The second stage includes applying the building loads to pile caps using eight incremental loadings. At this stage, the displacements of the initial and first stages of analysis were reset to zero in order to facilitate the study of the influence of shield tunneling on pile cap behavior.

4. The third stage simulates the advancement of the tunnel and the excavation of the first ring and replaced it with the shield every $3 \mathrm{~m}$. The drilling pressure and shield external pressure are activated.

5. Stages from 4 to 6: shield advancement, application of the drilling pressure and the shield external pressure, erecting the first ring of the segment inside the shield and applying the jacking force on it.

6. Stages from 7 to 10: Erecting four rings behind the shield and applying the segment external pressure.

7. Stage 11: erecting the next ring and the grout is considered hardened by changing the material properties.

8. Stages from 12 to 46 : Repeat stages (3-7) and continue digging until all segments are completed.

Table 3 reveals the activation (Install element) and the re-activation (Remove element) of the structural elements during tunnel construction stages by using Midas stage definition wizard, from stage 1 to stage 10, as they are done in the Midas GTX NX Software to prepare the 3D FEM model.

Table 3. Tunnel construction stages by using Midas-Wizard analysis.

\begin{tabular}{lcccccccccc}
\hline Set Name Prefix & S1 & S2 & S3 & S4 & S5 & S6 & S7 & S8 & S9 & S10 \\
\hline \multirow{2}{*}{ Shield } & \multirow{2}{*}{ A:1 } & \multirow{2}{*}{ A:2 } & \multirow{2}{*}{ A:3 } & \multirow{2}{*}{ A:4 } & A:5 & A:6 & A:7 & A:8 & A:9 & A:10 \\
& & & & & R:2 & R:3 & R:4 & R:5 & R:6 \\
\hline Segment & & & & A:1 & A:2 & A:3 & A:4 & A:5 & A:6 & A:7 \\
\hline Drilling pressure & A:1 & A:2 & A:3 & A:4 & A:5 & A:6 & A:7 & A:8 & A:9 & A:10 \\
\hline \multirow{2}{*}{ Jack thrust } & & & & \multirow{2}{*}{ A:1 } & A:2 & A:3 & A:4 & A:5 & A:6 & A:7 \\
& & & & R:1 & R:2 & R:3 & R:4 & R:5 & R:6 \\
\hline Shield external pressure & A:1 & \multirow{2}{*}{ A:2 } & A:3 & A:4 & A:5 & A:6 & A:7 & A:8 & A:9 & A:10 \\
\hline Segment external pressure & & & & & A:1 & A:2 & A:3 & A:4 & A:5 & A:6 \\
\hline Hard grout & & & & & & & & A:1 & A:2 & A:3 \\
\hline
\end{tabular}

Where S: Stage Number; A: Activated; R: Re-activated. 


\section{Verification of the Numerical Model}

There are five field measurements (SSP. B, SSP. C, SSP. D, SSP. E, and SSP. F) of longitudinal surface settlement that had been monitored which were located near the Garage El-Attaba building as shown in Figure 2. To ensure the validity of the numerical model results, a comparison has been conducted between the field measurements of these points with numerical results as shown in the following Figure 7, and the comparison has indicated a good agreement between the numerical and the measured values.
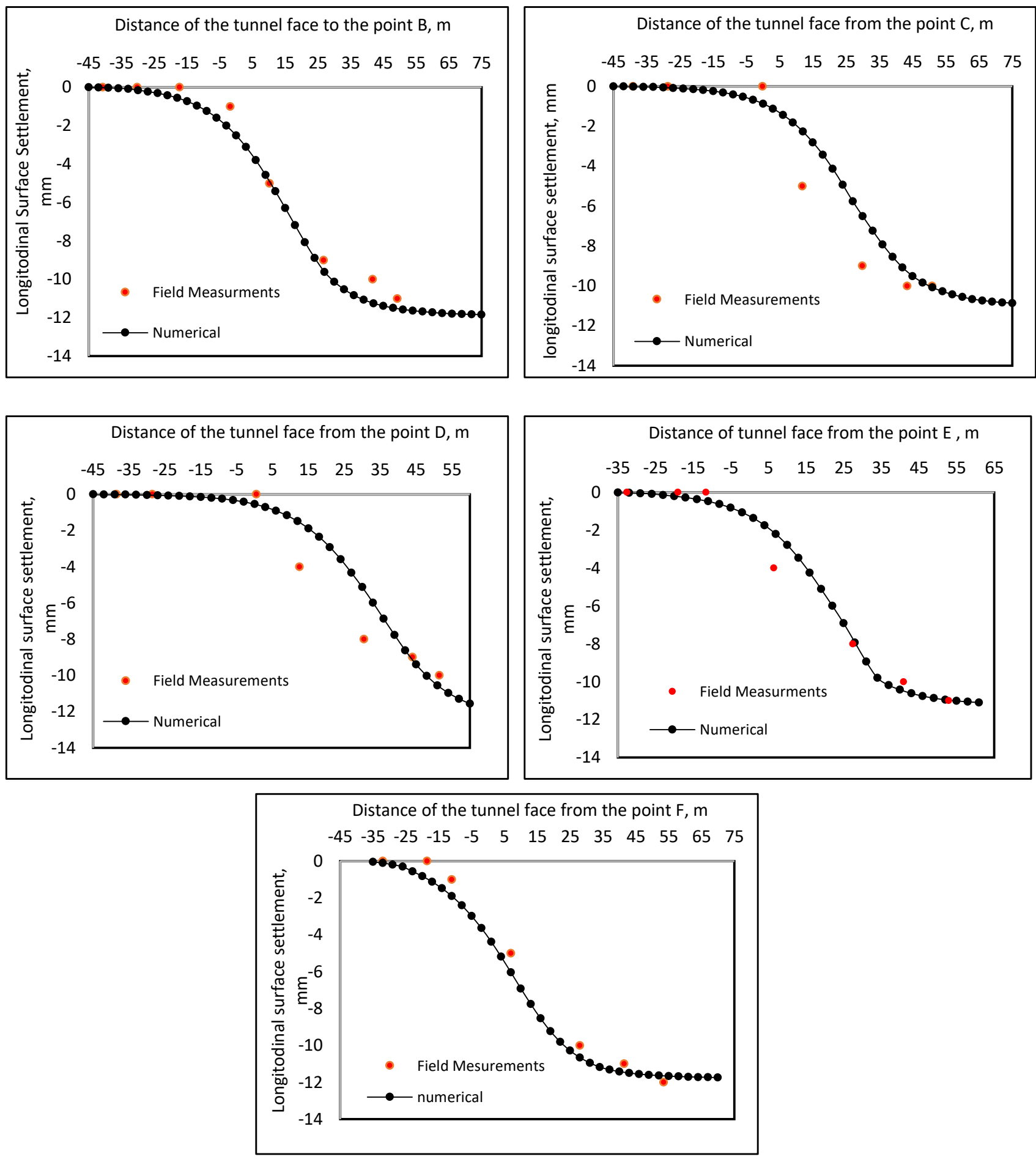

Figure 7. The longitudinal surface settlement at different points relative to tunnel advancement. 


\section{Numerical Results and Discussion}

\subsection{Influence of the Tunnel Excavation on the Piles Caps Foundations}

In order to study the behavior of piles caps due to tunneling construction, the axial settlement of 17 piles that connect with four caps was measured before and after tunnel construction as shown in Figure 8. As expected, due to the stress release caused by the tunnel construction, the pile settlement becomes larger than before tunneling. In addition, the results indicate that the nearest pile cap to the tunnel (PC1) was affected by the tunnel progress and the larger settlement occurring on it by about $60 \%$ to $70 \%$. After that, the piles settlements are roughly independent of their locations relative to the tunnel route. Therefore, the following sections have concerned with the pile (PC1) only.

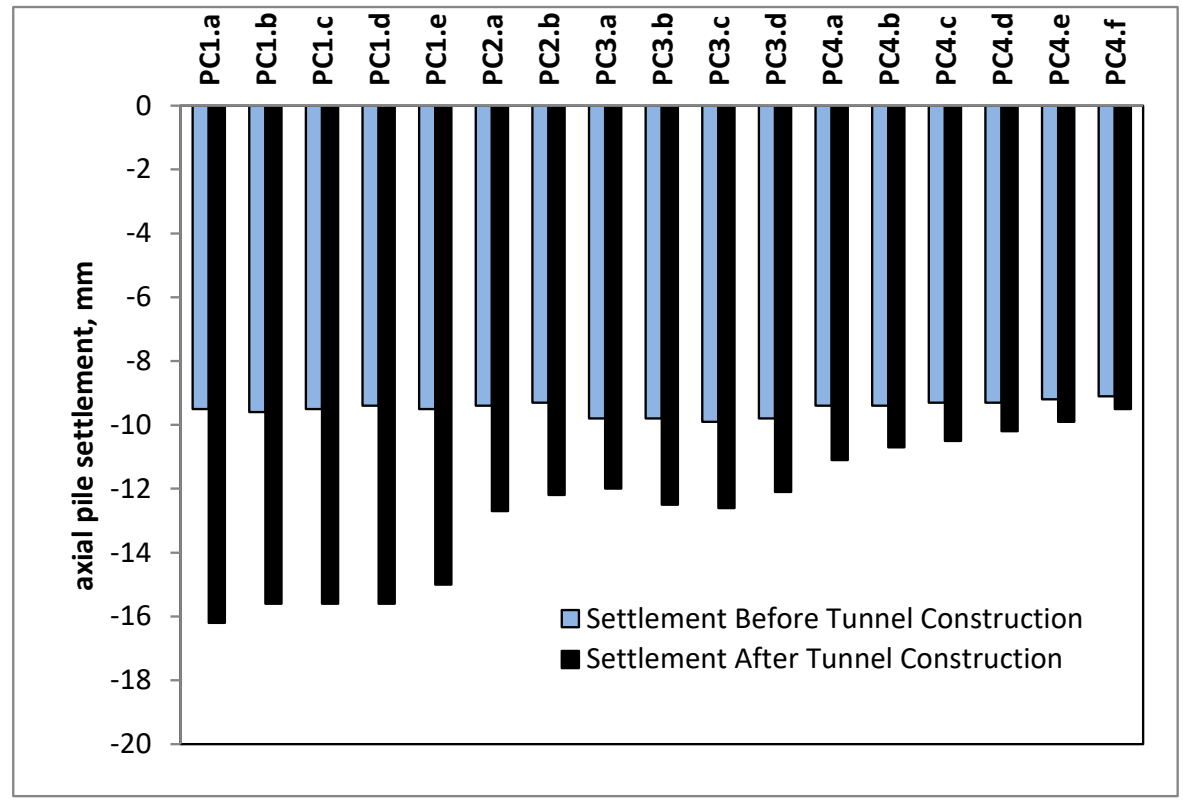

Figure 8. The pile axial settlement before and after tunnel construction.

5.2. Response of an Existing Pile Cap Foundation (PC1) to Tunneling-Induced Ground Movements with Different Construction Stages

The axial settlement, lateral deflection, axial force, and bending moment behaviors of the piles cap foundation (PC1) during different construction stages are discussed. In this study, different construction stages are $\left(Y=-2 D_{\text {tun }}, Y=0, Y=+2 D_{\text {tun }}\right.$, and $\left.Y=+4 D_{\text {tun }}\right)$, where $\mathrm{Y}$ is the distance between the tunnel face and center of $\mathrm{PC} 1$, and $\mathrm{D}_{\text {tun }}$ is the diameter of the tunnel. Fundamental to note that the pile near to the tunnel is titled the "Near" pile and the pile further away from the tunnel is the "Rear" pile, while the pile between them is the "Middle" pile.

Figure 9 shows the behavior of the axial settlement of the Near, Middle, and Rear piles for the PC1 foundation that adjacent to the tunnel at different tunnel construction stages. The results indicate that the axial settlement behavior is the same in all the construction stages for Near, Middle, and Rear piles. Meanwhile, the maximum settlement is measured at the pile head and reduced slightly at the pile tip located above the tunnel. In addition, the axial settlement of the Near pile is higher than that observed for the Middle and Rear piles in all construction stages. Overall, when the tunnel face is at $\left(Y=-2 D_{\text {tun }}\right)$ from the PC1, the axial settlement of the pile is approximately uniform along the pile side due to the strong stiffness of the pile [51]. After that, there is a significant increase in the axial settlement when the tunnel face approaches the center of the PC1 $(Y=0)$, while it moreover increases when the tunnel passes away from the PC1 $\left(Y=+2 D_{\text {tun }}\right)$ and $\left(Y=+4 D_{\text {tun }}\right)$. Finally, the pile settlement increase becomes negligible. 


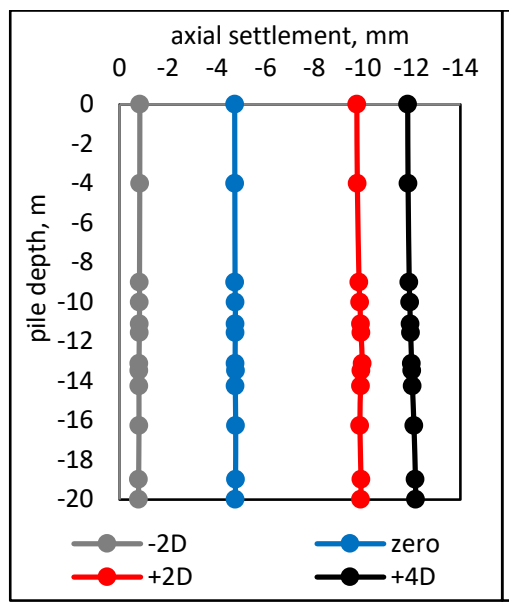

(a)

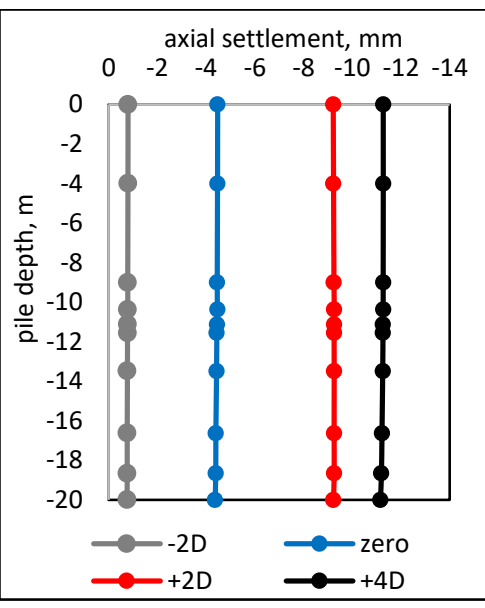

(b)

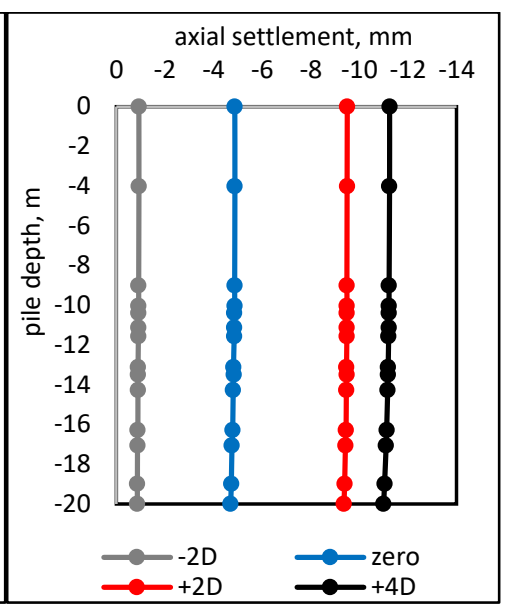

(c)

Figure 9. Axial settlement with a depth of (a) Near, (b) Middle, and (c) Rear piles at different construction stages.

In order to understand the lateral deflection of the PC1 foundation due to the tunnel excavation at different construction stages, Figure 10 presents the variations of lateral deflection behaviors of the Near, Middle, and Rear piles for PC1. The results indicate that the lateral deflection behavior is the same in all the construction stages for all piles, and the maximum lateral deflection occurs at the pile head and gradually decreases along the pile depth to be smaller at the pile tip. Again, the measured lateral deflection of the Near pile is noted to be higher than that observed from others, and this can be attributed to the volume loss induced around the tunnel when the distance from the tunnel decreases. In addition, it can be noted that when the tunnel face is reaching the PC1 foundation, there is only a slight translation of the pile $\left(\mathrm{Y}=-2 \mathrm{D}_{\text {tun }}\right)$. While at $(\mathrm{Y}=0)$, there is a significant amount of lateral deflection of the pile. After that, when the tunnel face is further away from the PC1 at $\left(Y=+2 D_{\text {tun }}\right.$ and $\left.Y=+4 D_{\text {tun }}\right)$, the pile deflection increases. Finally, the lateral deflection is roughly stagnating.

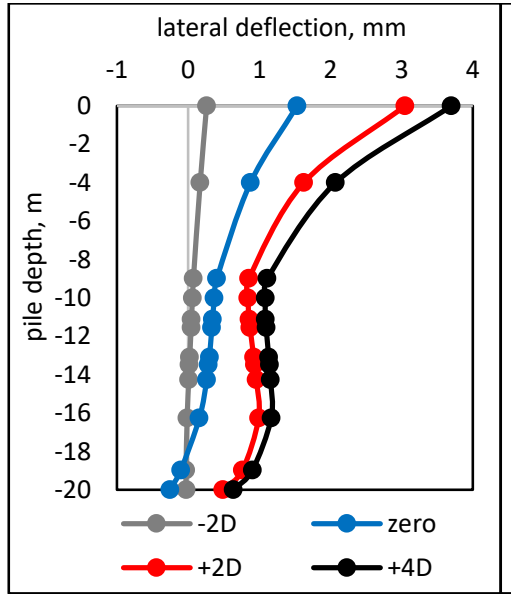

(a)

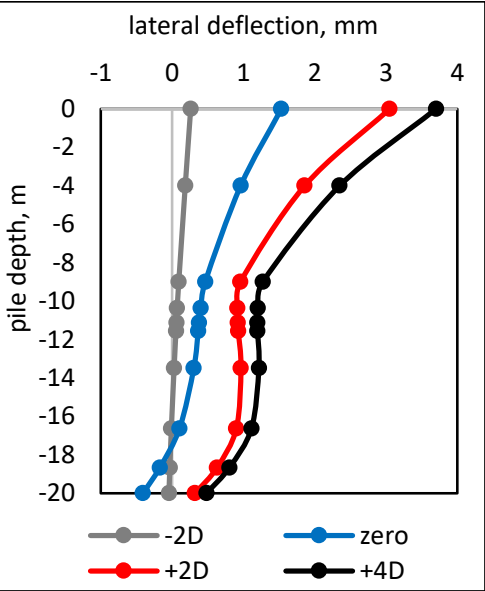

(b)

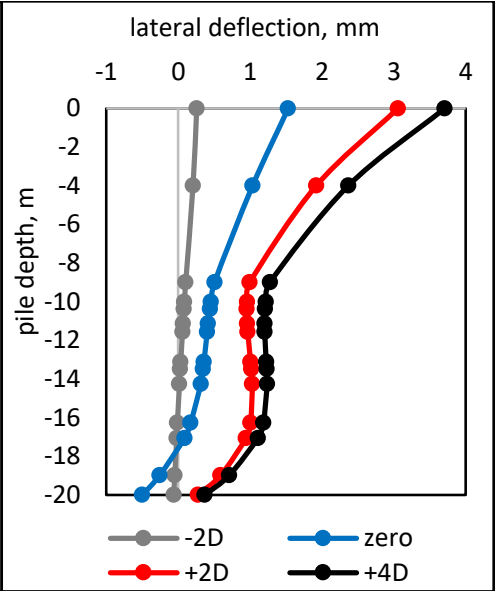

(c)

Figure 10. Lateral deflection with a depth of (a) Near, (b) Middle, and (c) Rear piles at different construction stages.

Figure 11 presents the behavior of the axial force of Near, Middle, and Rear piles of PC1. It can be realized that axial force for the Near pile approximately equal at the pile head at different stages and increases up to its maximum value at the pile depth $(16 \mathrm{~m})$ followed by a decrease due to the ground movement caused by the tunnel excavation. In general, when the tunnel face is reaching the PC1 foundation, there is only a small amount 
of axial force induced in the pile $\left(Y=-2 D_{\text {tun }}\right)$. After that, when the tunnel face reaches the center of the PC1 $(\mathrm{Y}=0)$, there is a slight increase in axial force. Moreover, it can be seen also that the maximum axial force is detected when the tunnel face is further away from the $P C 1$ at $\left(Y=+2 D_{\text {tun }}\right)$. After the passage of the tunnel face the $P C 1$ at $\left(Y=+4 D_{\text {tun }}\right)$, there is a decrease of the axial force. Again, the measured axial force of the Near pile is higher than that observed from others.

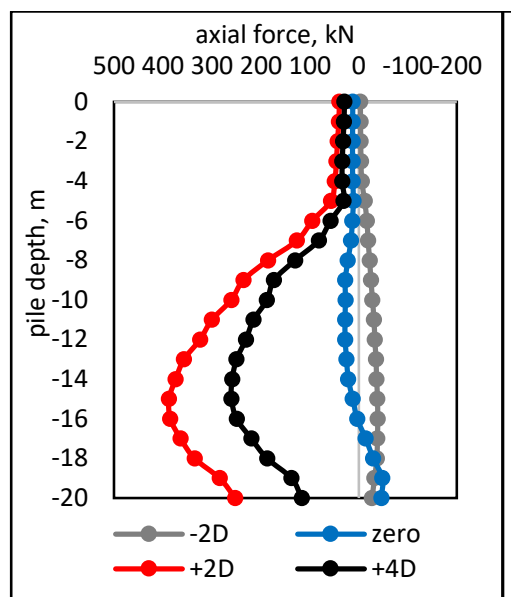

(a)

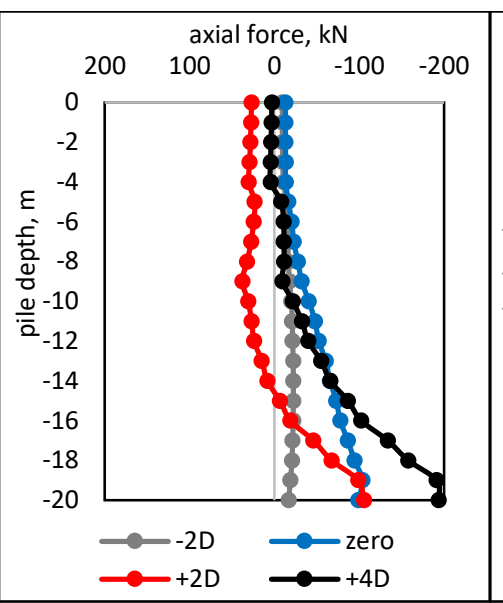

(b)

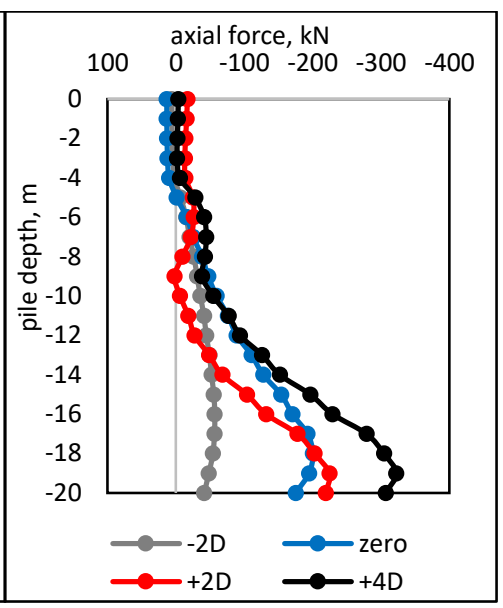

(c)

Figure 11. Axial force with a depth of (a) Near, (b) Middle, and (c) Rear piles at different construction stages.

Additionally, Figure 12, illustrates the behavior of the bending moment along the Near, Middle, and Rear piles of the PC1 foundation during different construction stages. The results point to the maximum bending moment occurring almost at the bottom of the piles due to the large lateral soil displacement around the tunnel. Meanwhile, the measured bending moment of the Near piles is double the value observed for the Middle and Rear piles. In general, the bending moment along the pile length is almost straight when the tunnel reached $\left(Y=-2 D_{\text {tun }}\right)$, while there is a significant amount of bending moment induced in the pile tip at the center of PC1 $(Y=0)$. The maximum bending moment is detected almost tripled when the tunnel face is further away from the PC1 at $\left(Y=+2 D_{\text {tun }}\right)$. After that, little change in maximum bending moment occurs at $\left(\mathrm{Y}=+4 \mathrm{D}_{\text {tun }}\right)$.

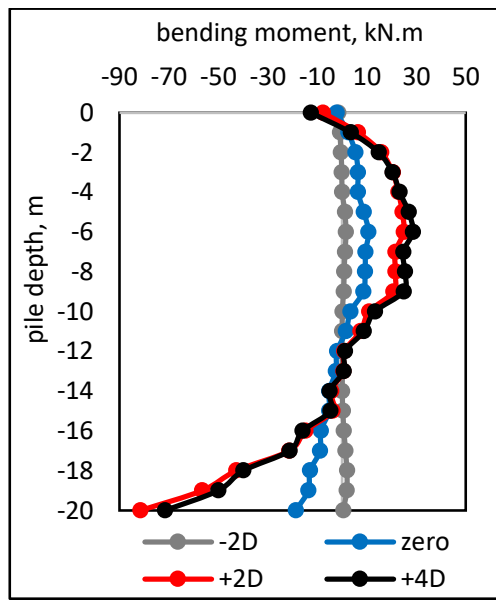

(a)

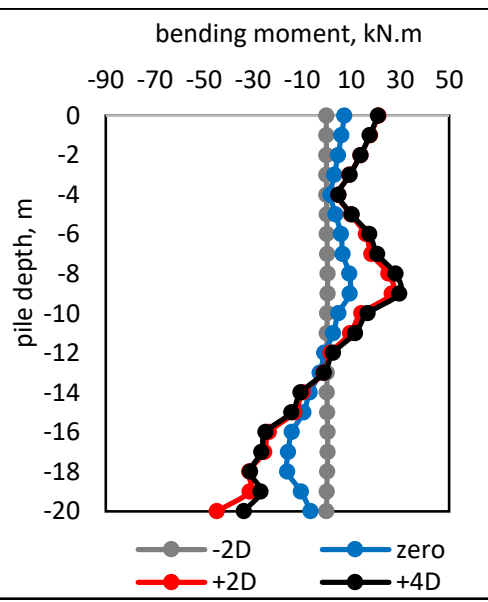

(b)

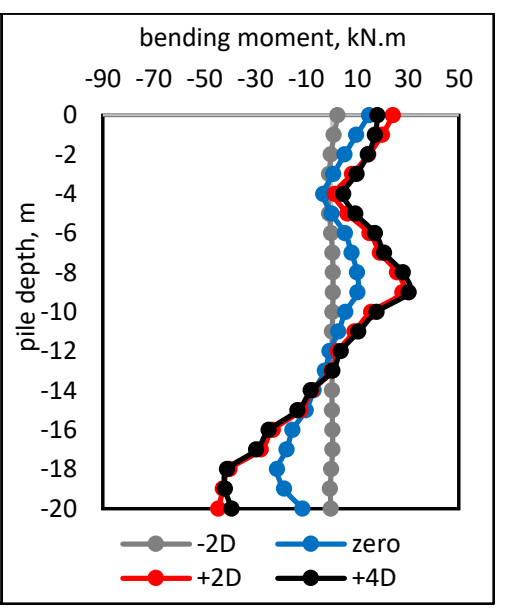

(c)

Figure 12. Bending moment with a depth of (a) Near, (b) Middle, and (c) Rear piles at different construction stages. 


\subsection{Parametric Studies}

A series of parametric studies are investigated by varying the tunnel-pile distance $\left(\mathrm{X}_{\text {pile }}\right)$, the diameter of the tunnel $\left(\mathrm{D}_{\text {tun }}\right)$ at different tunnel axis $(\mathrm{H})$. The whole study is categorized into two cases; deep tunnel where the tunnel axis is located below the tip, $(\mathrm{Lp} / \mathrm{H}<1)$ and shallow tunnel where the tunnel axis is located above the tip $(\mathrm{Lp} / \mathrm{H}>1)$. Figure 13 shows the flowchart of the parametric studies.

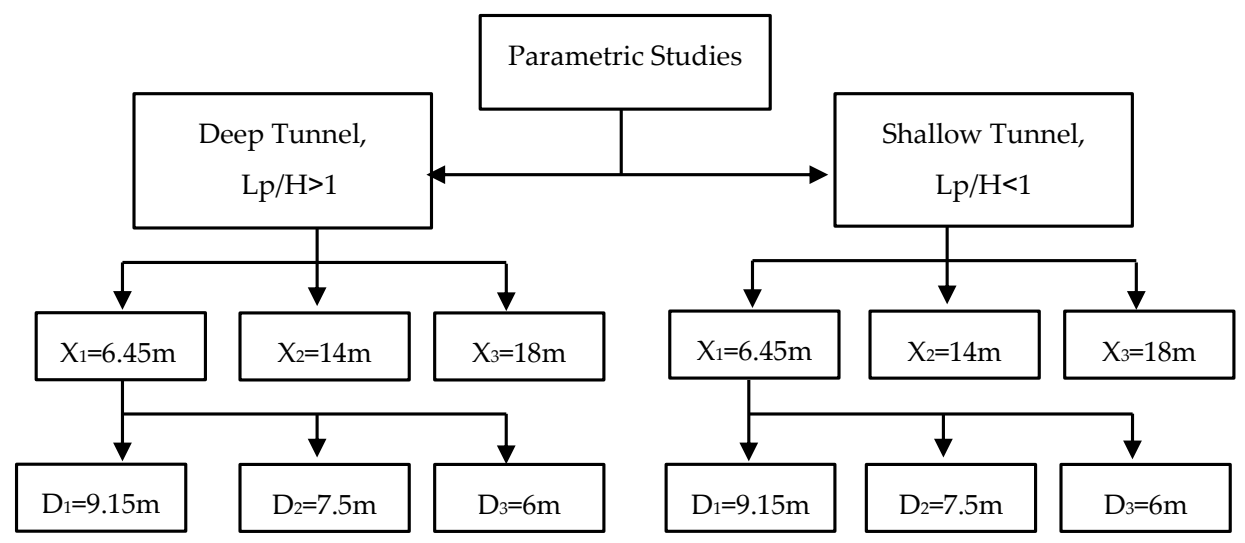

Figure 13. Flowchart of the parametric studies.

\subsubsection{Axial Settlement of the Piles}

Figures 14 and 15 illustrate the axial settlement amount of the Near, Middle, and Rear piles for deep and shallow tunnel respectively at various $X_{\text {pile }}(6.45,14$, and 18$) \mathrm{m}$ with a constant diameter $D_{\text {tun }}$ of $9.15 \mathrm{~m}$. The results indicate that in the axial settlement for both cases, the deep and shallow tunnel reaches the peak value when the pile offset about $6.45 \mathrm{~m}$ because the tunnel effect decreases when distance increases, and finally the tunnel effect fades when the pile is at a distance of about twice the diameter of the tunnel. The increase of the axial settlement is due to the additional settlement resulting during the construction of the tunnel. Meanwhile, the axial settlement in the case of the deep tunnel is approximately three times the settlement in the shallow tunnel. Moreover, in the case of the deep tunnel, the axial settlement is approximately uniform while in the shallow tunnel the maximum axial settlement is noted at the pile head and gradually decreased to reach a minimum value at the pile tip due to the tunneling effect only on the upper portion of the pile. In general, for both cases, the axial settlement of the Near, Middle, and Rear piles increases as the distance between the pile and the tunnel decreases. The results indicate a good agreement with the findings of $[13,52]$.

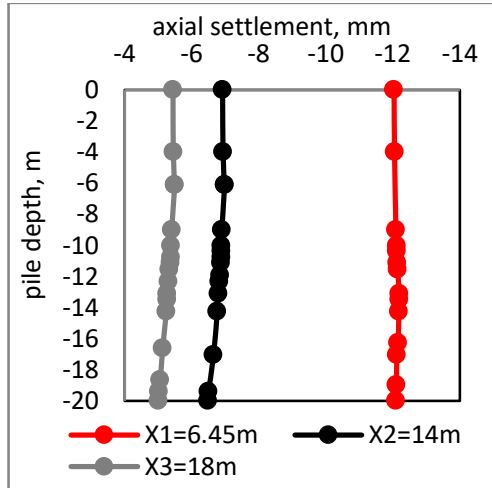

(a)

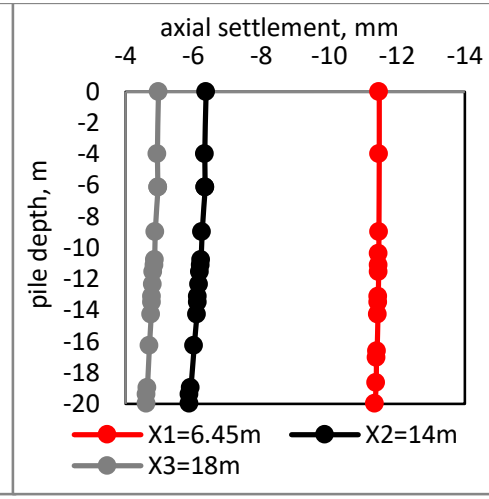

(b)

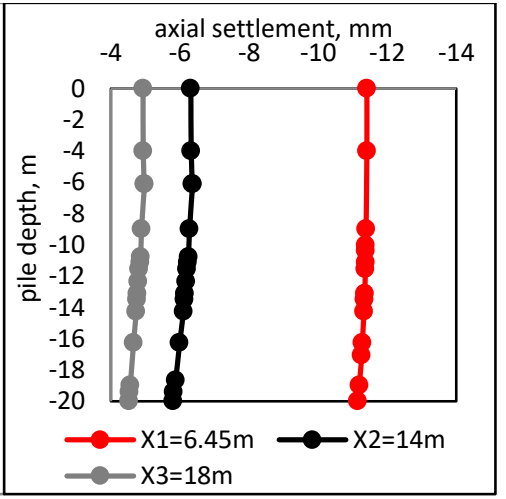

(c)

Figure 14. Axial settlement at a depth of (a) Near, (b) Middle, and (c) Rear piles with different $X_{\text {pile }}$ for the deep tunnel $(\mathrm{H}=26 \mathrm{~m})$. 


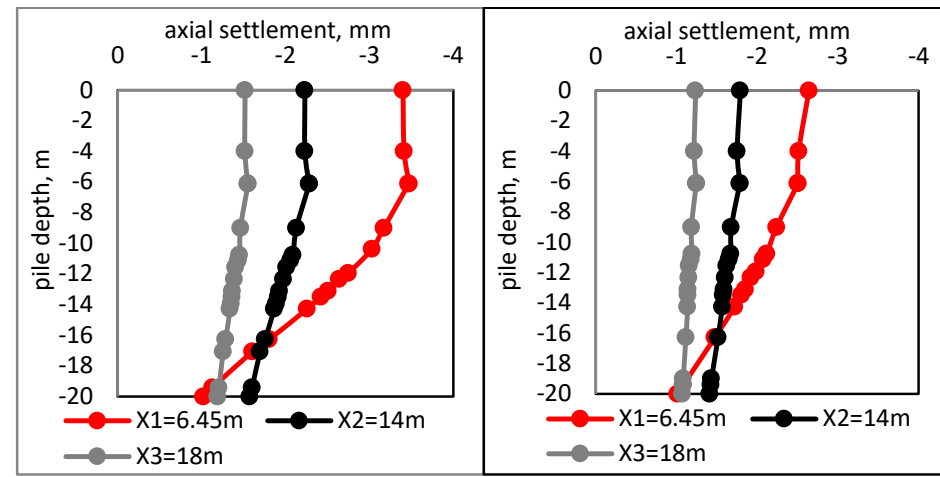

(a)

(b)

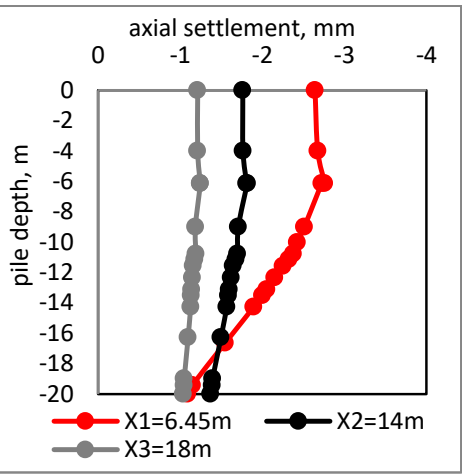

(c)

Figure 15. Axial settlement at a depth of (a) Near, (b) Middle, and (c) Rear piles with different $X_{\text {pile }}$ for the shallow tunnel $(\mathrm{H}=14 \mathrm{~m})$.

On the other hand, Figures 16 and 17 illustrate the axial settlement of the Near, Middle, and Rear piles for the deep and shallow tunnel, respectively, at various $\mathrm{D}_{\text {tun }}(9.15,7.5$, and 6) $\mathrm{m}$ with constant distance $X_{\text {pile }}$ of $6.45 \mathrm{~m}$. For both cases, it can be seen that the axial settlement of the Near, Middle, and Rear piles is almost higher when $D_{\text {tun }}=9.15 \mathrm{~m}$ and decreases with the decreases in the tunnel diameter. This result well agrees with those conducted by [52]. In addition, the axial settlement of the pile occurred uniformly along its length owing to the high stiffness of the pile in the case of the deep tunnel while nonuniform in the case of the shallow tunnel.

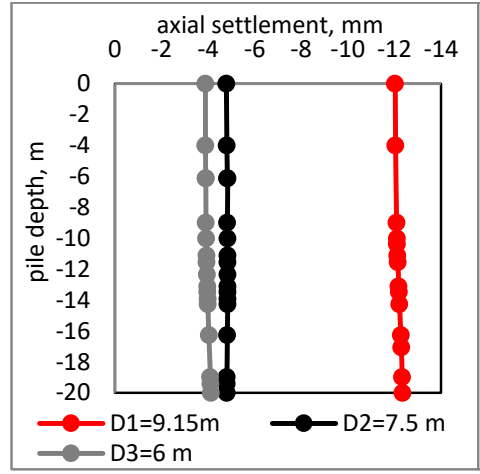

(a)

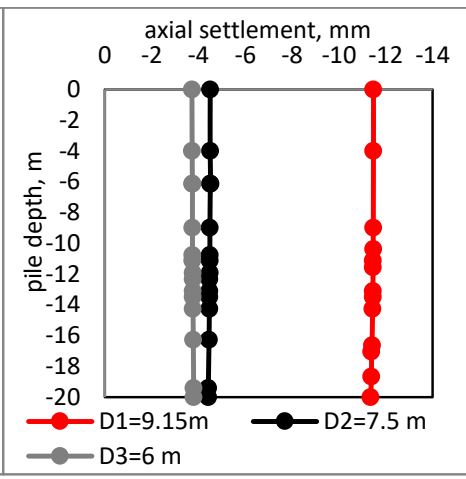

(b)

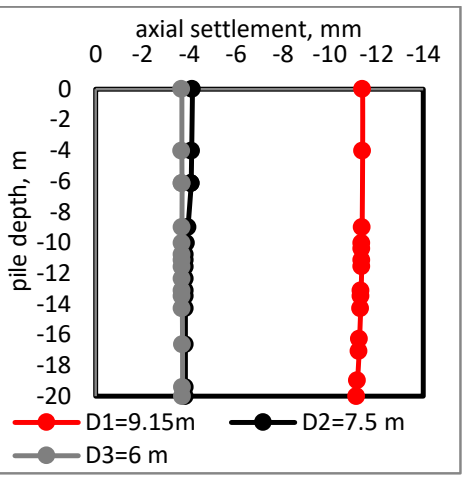

(c)

Figure 16. Axial settlement at a depth of (a) Near, (b) Middle, and (c) Rear piles with different $D_{\text {tun }}$ for the deep tunnel $(\mathrm{H}=26 \mathrm{~m})$.

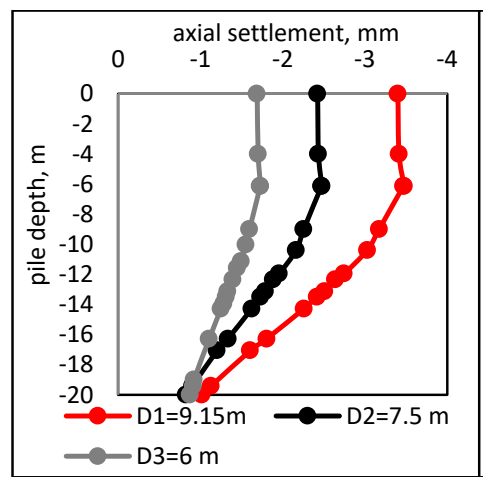

(a)

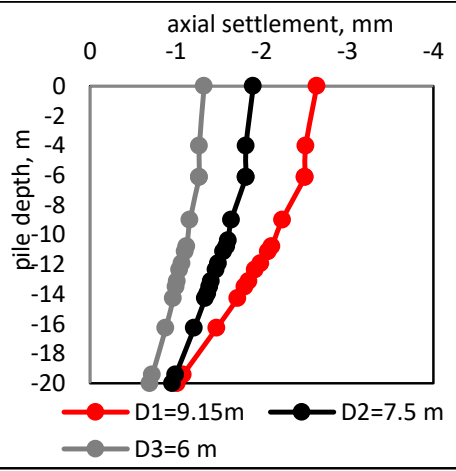

(b)

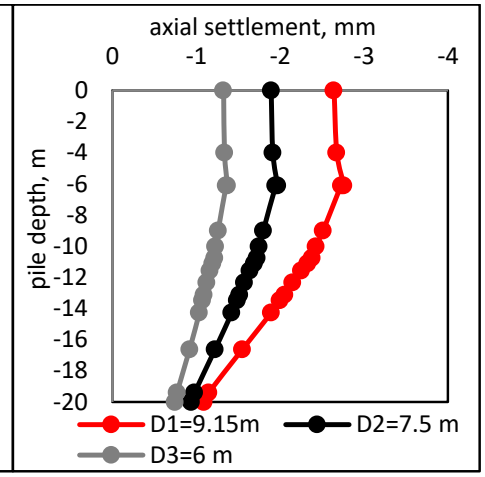

(c)

Figure 17. Axial settlement at a depth of (a) Near, (b) Middle, and (c) Rear piles with different $\mathrm{D}_{\text {tun }}$ for the shallow tunnel $(\mathrm{H}=14 \mathrm{~m})$. 
Finally, it can be concluded that for all cases, the axial settlement of the Near piles is higher than the Middle and Rear piles. Furthermore, it can be noted that in the case of the shallow tunnel $(\mathrm{Lp} / \mathrm{H}<1)$ the axial settlement is less than that of the deep tunnel $(\mathrm{Lp} / \mathrm{H}>1)$. This result agrees with those obtained by [44].

\subsubsection{Lateral Deflection of the Piles}

Figures 18 and 19 present the comparison of the lateral deflection behavior of the Near, Middle, and Rear piles for the deep and shallow tunnel at various $X_{\text {pile }}(6.45,14$, and 18) $\mathrm{m}$ and constant tunnel diameter $\mathrm{D}_{\text {tun }}$ of $9.15 \mathrm{~m}$. As it can be seen, the lateral deflection at the pile head is higher than the pile tip, owing to the upper part of the tunnel which has a larger volume of over-cut than the lower part where the restraining effect happened [44]. In addition, an increase in the distance between the tunnel and the pile does not further affect the maximum values of lateral deflection in contrast to the tunnel depth [52].

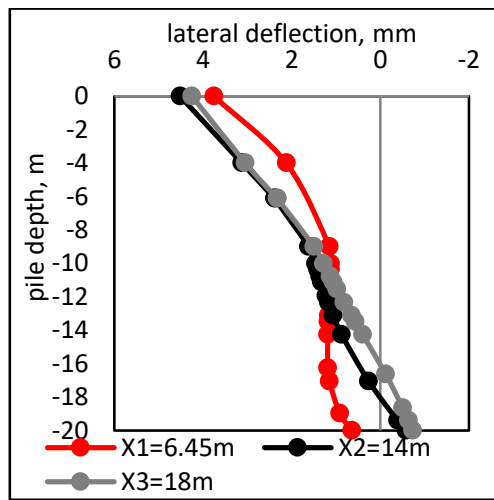

(a)

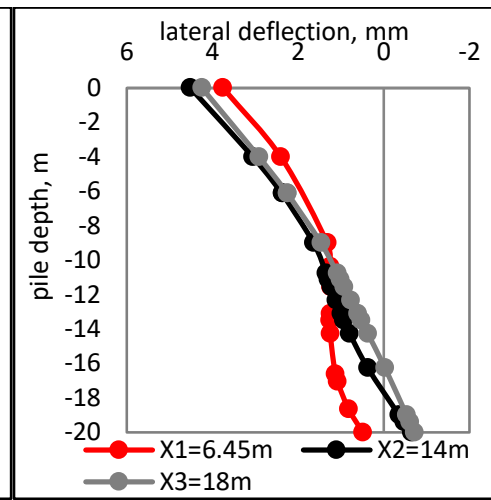

(b)

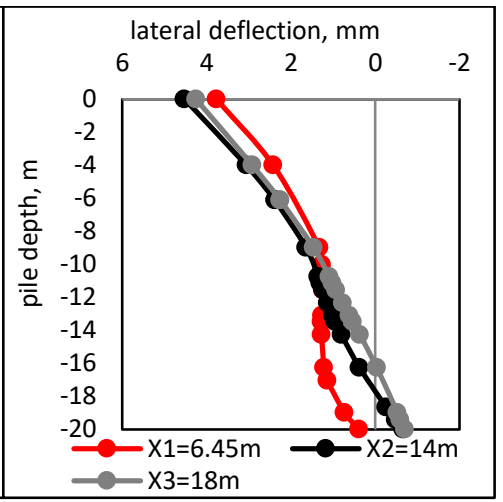

(c)

Figure 18. Lateral deflection at a depth of (a) Near, (b) Middle, and (c) Rear piles with different $X_{\text {pile }}$ for the deep tunnel $(\mathrm{H}=26 \mathrm{~m})$.

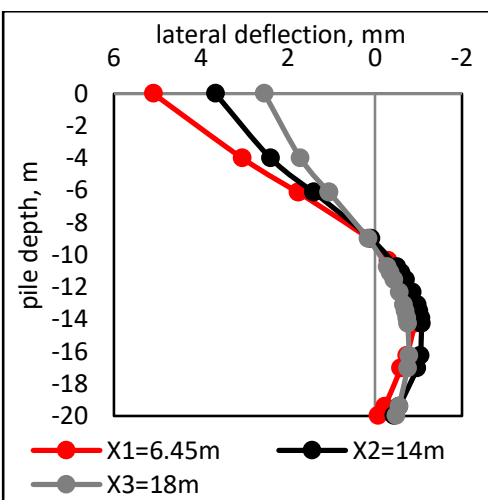

(a)

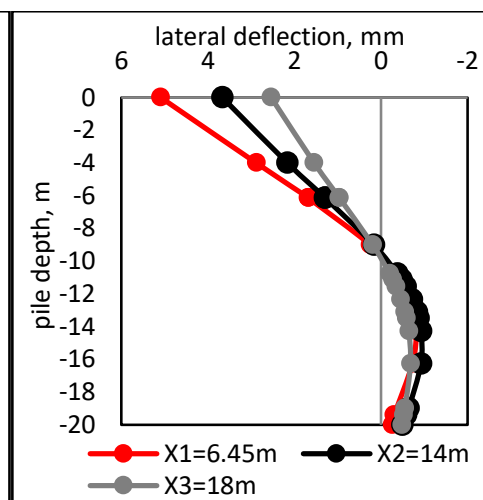

(b)

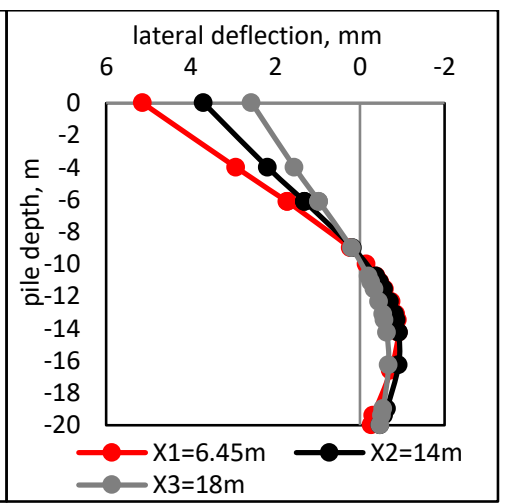

(c)

Figure 19. Lateral deflection at a depth of (a) Near, (b) Middle, and (c) Rear piles with different $X_{\text {pile }}$ for the shallow tunnel $(\mathrm{H}=14 \mathrm{~m})$.

Moreover, Figures 20 and 21 show the lateral deflection behavior of the Near, Middle, and Rear piles for the deep and shallow tunnel at various $D_{\text {tun }}(9.15,7.5$, and 6) $\mathrm{m}$ and constant distance $X_{\text {pile }}$ of $6.45 \mathrm{~m}$. As expected, an increase in the tunnel diameter causes an increase in the lateral deflection due to tunneling induced ground movement and the stress release which in turn affect the piles. The results indicate a good agreement with the work of [52]. 


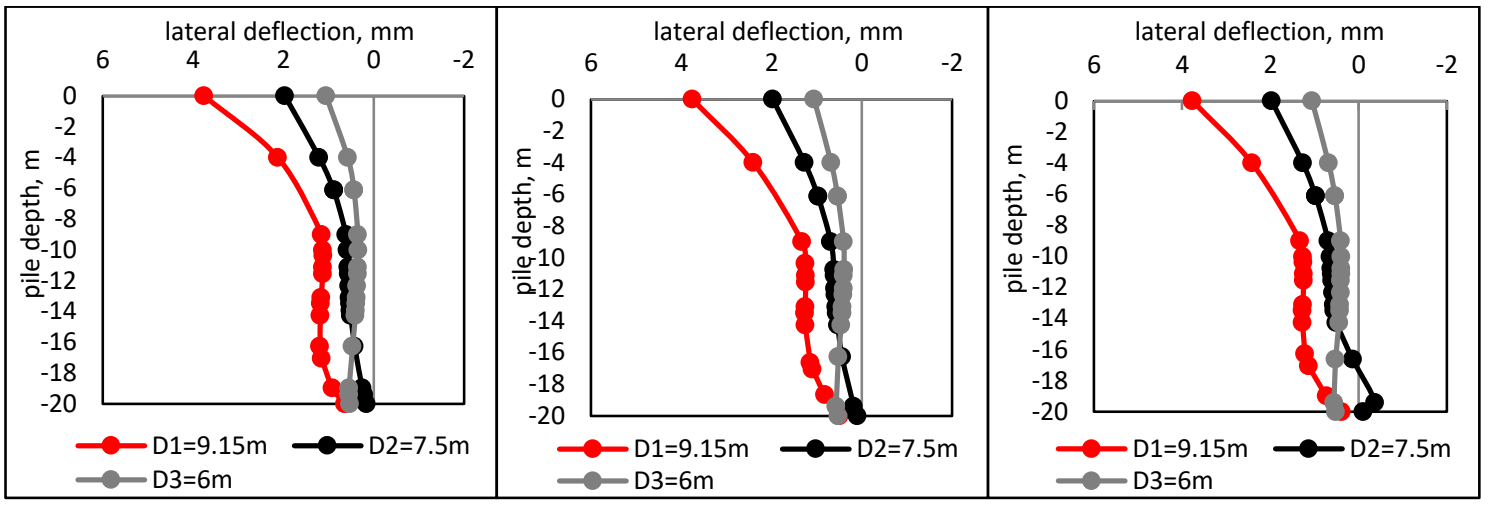

(a)

(b)

(c)

Figure 20. Lateral deflection at a depth of (a) Near, (b) Middle, and (c) Rear piles with different $\mathrm{D}_{\text {tun }}$ for the deep tunnel $(\mathrm{H}=26 \mathrm{~m})$.

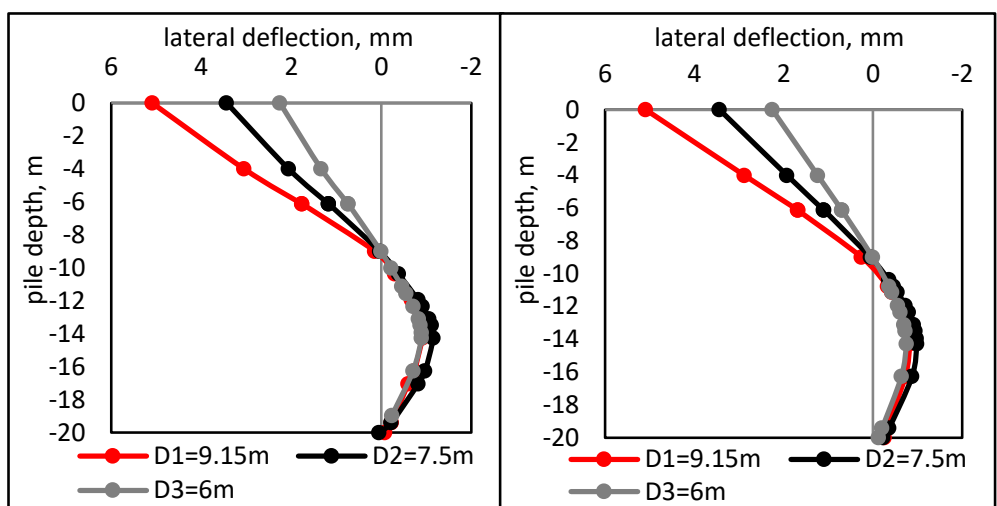

(a)

(b)

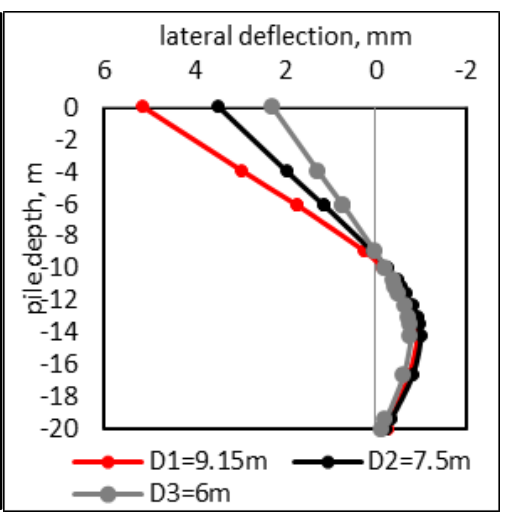

(c)

Figure 21. Lateral deflection at a depth of (a) Near, (b) Middle, and (c) Rear piles with different $D_{\text {tun }}$ for the shallow tunnel $(\mathrm{H}=14 \mathrm{~m})$.

\subsubsection{Axial Force of the Piles}

The developing axial force distribution along with the Near, Middle, and Rear piles at various pile positions $X_{\text {pile }}(6.45,14$, and 18) $\mathrm{m}$ relative to the deep and shallow tunnels with a constant diameter $D_{\text {tun }}$ of $9.15 \mathrm{~m}$ are demonstrated in Figures 22 and 23. For both cases, the axial force at the upper part of the pile does not affect by the tunnel excavation while the effect increases more significantly at the middle and lower partition of the pile. In addition, an increase in the distance between the pile and the tunnel does not cause much variation in the axial force. Furthermore, there is a significant effect in the amount of axial force at the Near pile while a small effect at the Middle and Rear piles in the case of the shallow tunnel. However, the induced maximum axial force at the Near pile is larger than that of the Middle and Rear pile for the deep and shallow tunnel. This result well agrees with the findings of $[52,53]$.

On the other hand, Figures 24 and 25 illustrate the axial force behavior for Near, Middle, and Rear piles located at a specific distance of about $6.45 \mathrm{~m}$ from the deep and shallow tunnel with various $\mathrm{D}_{\text {tun }}(9.15,7.5$, and 6) $\mathrm{m}$. Again, the axial force increases as the tunnel diameter increases. Moreover, the axial force increases by about $75 \%$ and $90 \%$ in the deep and shallow tunnel, respectively, with $\mathrm{D}=9.15 \mathrm{~m}$. This is due to the increase in ground movement around the tunnel construction. As in the case of the shallow tunnel, the axial force at the Near pile is significantly more affected. However, it can be concluded that higher-diameter tunnels induce a higher axial force on the piles. The axial force at the Near pile is larger than that of the middle and Rear pile for the deep and shallow tunnel. In 
general, additional axial forces can be induced in a pile due to tunnel construction, based on the location of piles relative to the tunnel. These results are similar to those obtained by $[44,52,53]$.

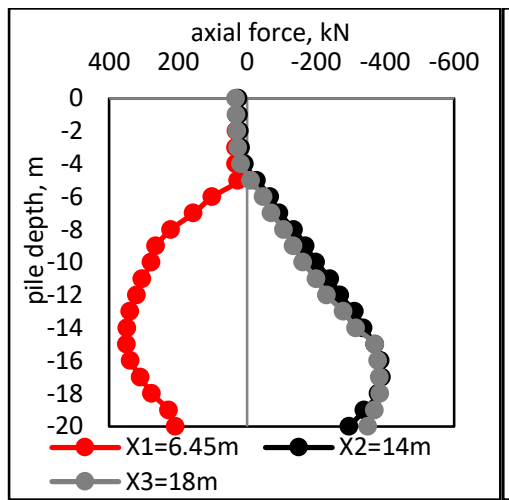

(a)

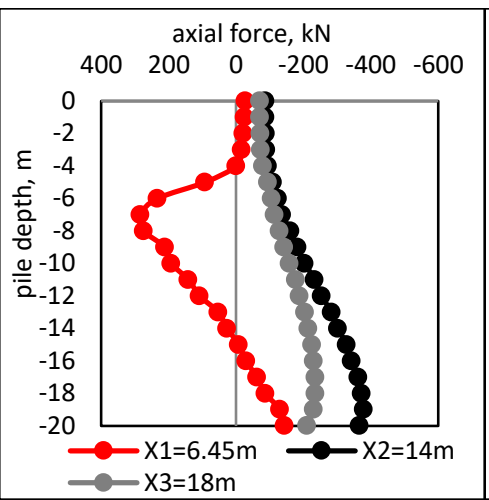

(b)

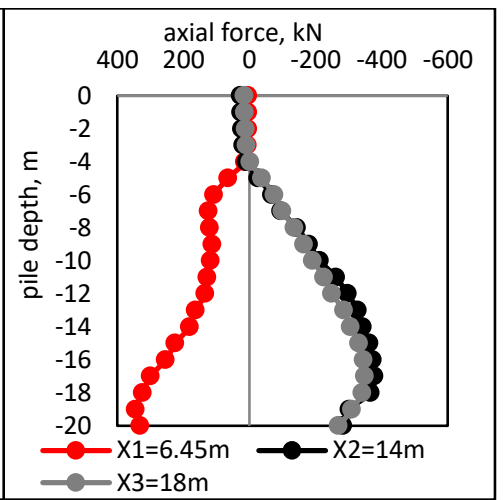

(c)

Figure 22. Axial force at depth of (a) Near, (b) Middle, and (c) Rear piles with different $X_{\text {pile }}$ for deep tunnel ( $\left.\mathrm{H}=26 \mathrm{~m}\right)$.

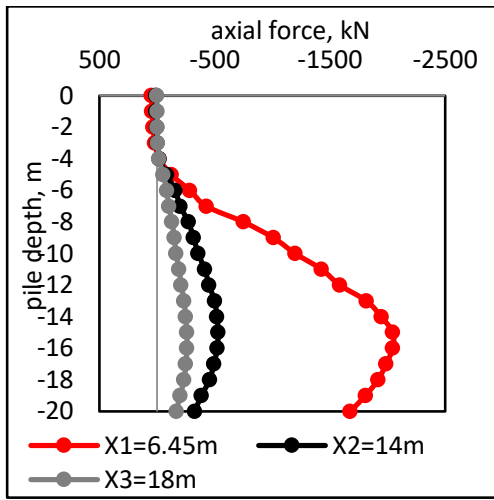

(a)

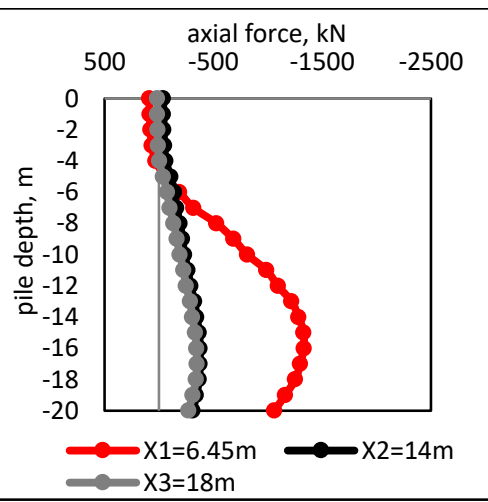

(b)

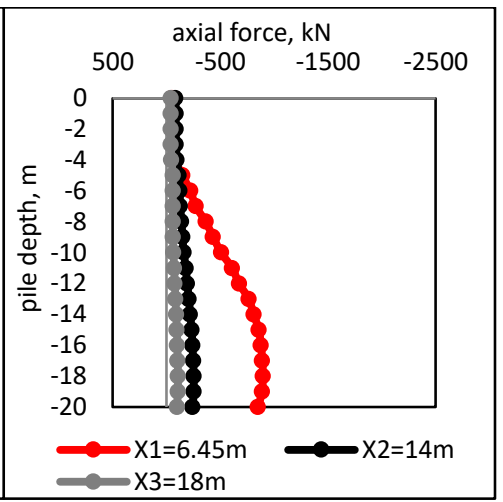

(c)

Figure 23. Axial force at a depth of (a) Near, (b) Middle, and (c) Rear piles with different $X_{\text {pile }}$ for the deep tunnel $(\mathrm{H}=26 \mathrm{~m})$.

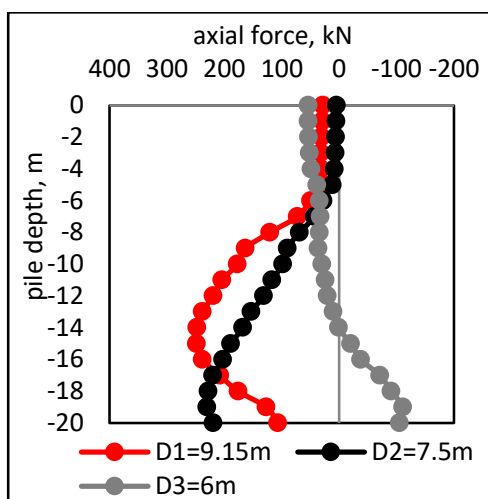

(a)

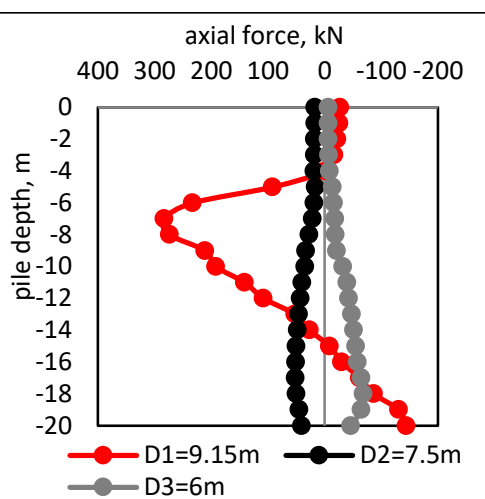

(b)

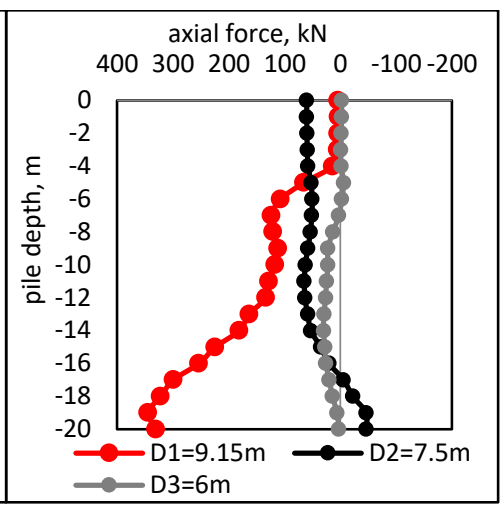

(c)

Figure 24. Axial force at a depth of (a) Near, (b) Middle, and (c) Rear piles with different $\mathrm{D}_{\text {tun }}$ for the deep tunnel $(\mathrm{H}=26 \mathrm{~m})$. 


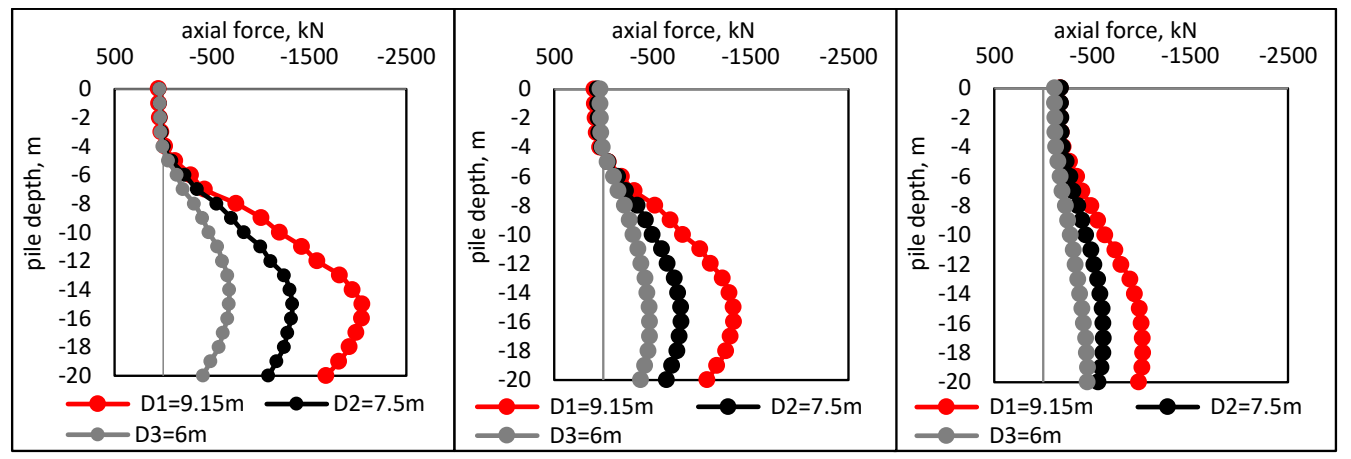

(a)

(b)

(c)

Figure 25. Axial force at a depth of (a) Near, (b) Middle, and (c) Rear piles with different $D_{\text {tun }}$ for the shallow tunnel $(\mathrm{H}=14 \mathrm{~m})$.

\subsubsection{Bending Moment of the Piles}

Figures 26 and 27 show the comparison of the bending moment behavior of the Near, Middle, and Rear piles at various $X_{\text {pile }}\left(6.45,14\right.$, and 18) $\mathrm{m}$ and constant $\mathrm{D}_{\text {tun }}$ of $9.15 \mathrm{~m}$ for the deep and shallow tunnel, respectively. It can be seen that the bending moment in both cases increased as the distance from the tunnel decreased due to lateral soil movement. This result is in good agreement with the work of [44,52]. For more details, the bending moment of the pile increases significantly as the tunnel construction reaching to the pile tip [54]. As expected, the pile that is closer to the tunnel is affected more by tunnel construction. In general, very little change in the bending moment may be noted at the distance $X_{\text {pile }}=14 \mathrm{~m}$ and $18 \mathrm{~m}$. Finally, it can be concluded that the maximum bending moment of the shallow tunnel $(\mathrm{Lp} / \mathrm{H}>1)$ is more than that of the deep tunnel $(\mathrm{Lp} / \mathrm{H}<1)$ [53].

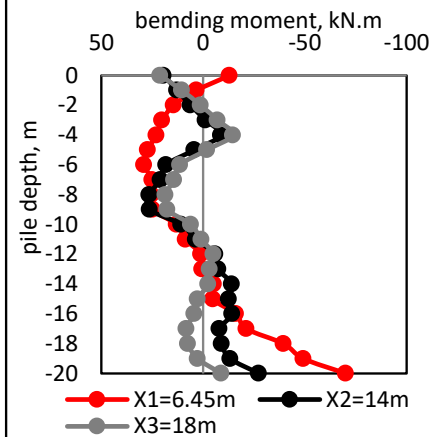

(a)

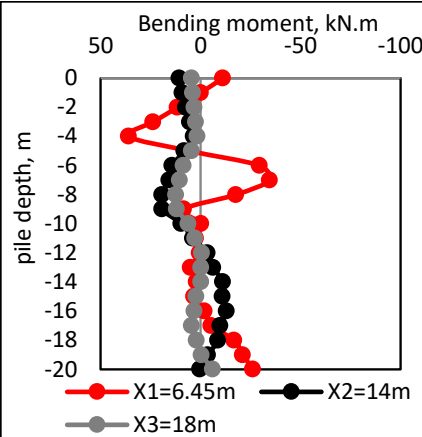

(b)

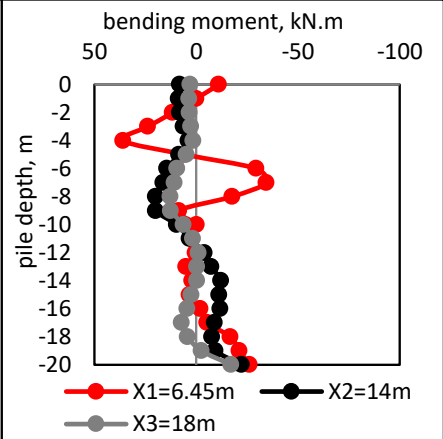

(c)

Figure 26. Bending moment at a depth of (a) Near, (b) Middle, and (c) Rear piles with different $X_{\text {pile }}$ for the deep tunnel $(\mathrm{H}=26 \mathrm{~m})$.

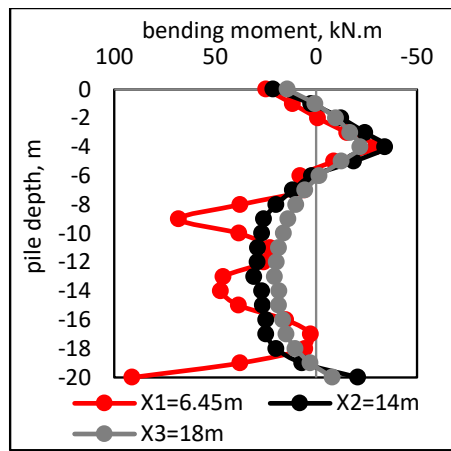

(a)

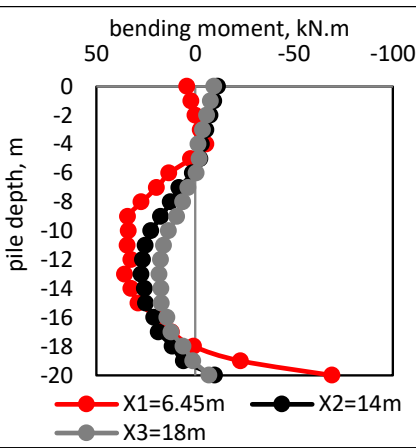

(b)

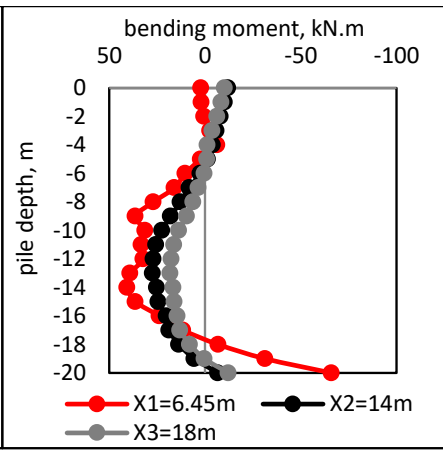

(c)

Figure 27. Bending moment at a depth of (a) Near, (b) Middle, and (c) Rear piles with different $X_{\text {pile }}$ for the shallow tunnel ( $\mathrm{H}=14 \mathrm{~m})$. 
On the other hand, Figures 28 and 29 show the bending moment profiles at various $D_{\text {tun }}\left(9.15,7.5\right.$, and 6) $\mathrm{m}$ and a constant $X_{\text {pile }}$ of $6.45 \mathrm{~m}$ for the deep and shallow tunnel, respectively. It can be seen that an increase in the diameter of the tunnel causes an increase in bending moment [52]. Moreover, the maximum bending moment occurs at the bottom partition of the piles. Again, the bending moment at the Near pile is larger than that of the Middle and Rear pile for the deep and shallow tunnel. Generally, very little change in the maximum bending moment can be noted for both cases.

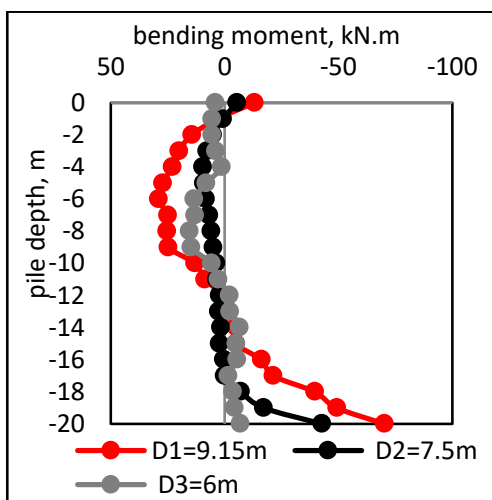

(a)

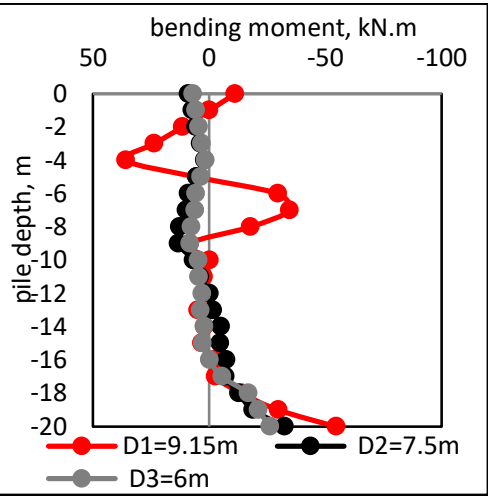

(b)

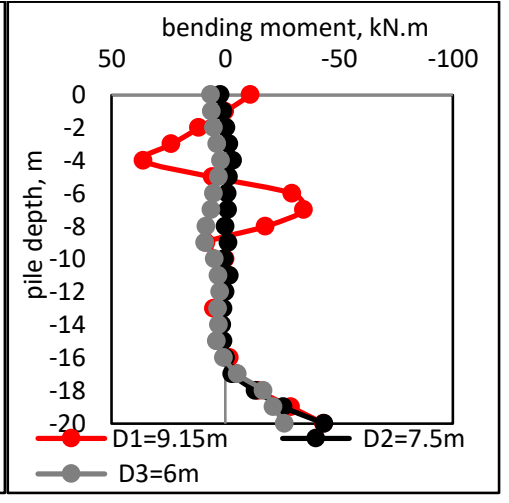

(c)

Figure 28. Bending moment at a depth of (a) Near, (b) Middle, and (c) Rear piles with different $\mathrm{D}_{\text {tun }}$ for the deep tunnel $(\mathrm{H}=26 \mathrm{~m})$.

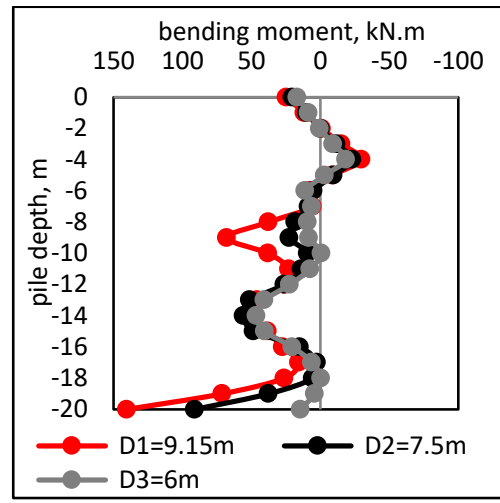

(a)

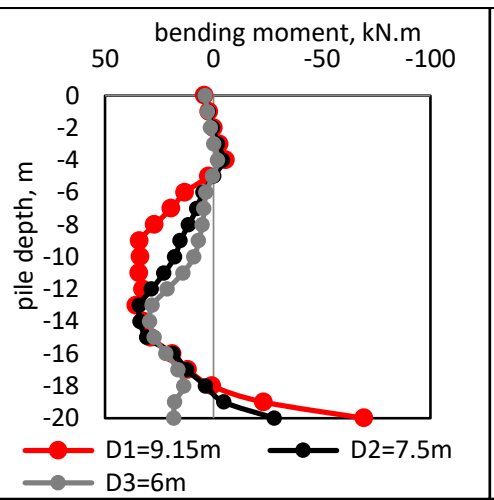

(b)

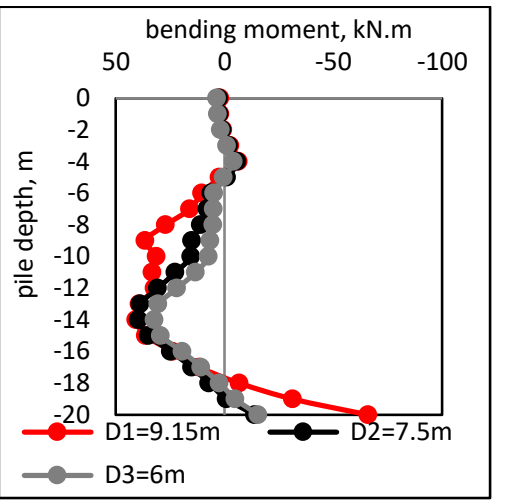

(c)

Figure 29. Bending moment at a depth of (a) Near, (b) Middle, and (c) Rear piles with different $\mathrm{D}_{\text {tun }}$ for the shallow tunnel $(\mathrm{H}=14 \mathrm{~m})$.

\section{Conclusions}

A series of 3D finite element modellings have been conducted using Midas GTSNX software to study the behavior of pile cap foundation for Garage El-Attaba building during the shield advancement of the Greater Cairo Metro Line 3-Phase 1 using Modified Mohr-Coulomb constitutive model. Investigation of the pile responses, including the axial settlement, lateral deflection, bending moment, and additional axial force by the tunnel construction stages were discussed. The present study shows that the pile responses are influenced by tunneling. In addition, various factors on the pile response were studied in which the following factors were included: the distance between the pile and the tunnel and the diameter of the tunnel with two different tunnel axes, deep and shallow tunnel. The following findings have been drawn from the study:

1. The tunnel depth has an adverse influence on the response of piles. As the depth of the tunnel increases, the response of the piles decreases. However, to avoid serious 
damage to the adjacent pile foundation and structures, the tunnel depth and distance between the piles and the tunnel must be taken into consideration, being important to control effectively the piles responses.

2. For both cases, deep and shallow tunnel, increasing the tunnel diameter causes the pile to increase the axial settlement and lateral deflection more as well as induce more additional axial force and bending moment.

3. Decreasing the distance between the tunnel and the pile does cause a significant effect on pile response. However, the behavior of the variation is the same for Near, Middle, and Rear piles.

4. For the deep tunnel (tunnel axis is located below the tip) and shallow tunnel (tunnel axis is located above the tip), the maximum bending moment and axial force occurred at the pile tip while the maximum axial settlement and lateral deflection occurred at the pile head.

5. Larger variation to the pile axial force and bending moment were observed in the case of the shallow tunnel. However, the depth of the tunnel axis has much significant effect on pile response. Hence, the shallow tunnel does cause a greater response on piles more than the deep tunnel.

Author Contributions: Conceptualization, M.A., H.Q., and X.Z.; formal analysis, M.A.; investigation, M.A., H.Q., and X.Z.; writing-original draft preparation, M.A. and H.Q.; supervision, H.Q., and X.Z. All authors have read and agreed to the published version of the manuscript.

Funding: The publishing of this paper is financially supported by the National Natural Science Foundation of China (No. 11672215).

Institutional Review Board Statement: Not applicable.

Informed Consent Statement: Not applicable.

Data Availability Statement: The data presented in this study are available on request from the corresponding author.

Conflicts of Interest: The authors declare no conflict of interest.

\section{References}

1. Attewell, P.B.; Farmer, I.W. Ground disturbance caused by shield tunnelling in a stiff, overconsolidated clay. Eng. Geol. 1974, 8, 361-381. [CrossRef]

2. Basile, F. Effects of tunnelling on pile foundations. Soils Found. 2014, 54, 280-295. [CrossRef]

3. Al-Omari, R.R.; Al-Soud, M.S.; Al-Zuhairi, O.I. Effect of Tunnel Progress on the Settlement of Existing Piled Foundation. Stud. Geotech. Mech. 2019, 41, 102-113. [CrossRef]

4. Wang, H.; Leung, C.F.; Yu, J.; Huang, M. Axial response of short pile due to tunnelling-induced soil movement in soft clay. Int. J. Phys. Model. Geotech. 2019, 20, 71-82. [CrossRef]

5. Li, Y.; Zhang, W. Investigation on passive pile responses subject to adjacent tunnelling in anisotropic clay. Comput. Geotech. 2020, 127, 103782. [CrossRef]

6. Simic-Silva, P.T.; Martínez-Bacas, B.; Galindo-Aires, R.; Simic, D. 3D simulation for tunnelling effects on existing piles. Comput. Geotech. 2020, 124, 103625. [CrossRef]

7. Jacobsz, S.W.; Standing, J.R.; Mair, R.J.; Hagiwara, T.; Sugiyama, T. Centrifuge modelling of tunnelling near driven piles. Soils Found. 2004, 44, 49-56. [CrossRef]

8. Franza, A.; Marshall, A.M. Centrifuge modeling study of the response of piled structures to tunneling. J. Geotech. Geoenviron. Eng. 2018, 144, 4017109. [CrossRef]

9. Lee, C.J. Numerical analysis of the interface shear transfer mechanism of a single pile to tunnelling in weathered residual soil. Comput. Geotech. 2012, 42, 193-203. [CrossRef]

10. Franza, A.; Marshall, A.M. Centrifuge and real-time hybrid testing of tunneling beneath piles and piled buildings. J. Geotech. Geoenviron. Eng. 2019, 145, 4018110. [CrossRef]

11. Soomro, M.A.; Hong, Y.; Ng, C.W.W.; Lu, H.; Peng, S. Load transfer mechanism in pile group due to single tunnel advancement in stiff clay. Tunn. Undergr. Space Technol. 2015, 45, 63-72. [CrossRef]

12. Soomro, M.A.; Ng, C.W.W.; Liu, K.; Memon, N.A. Pile responses to side-by-side twin tunnelling in stiff clay: Effects of different tunnel depths relative to pile. Comput. Geotech. 2017, 84, 101-116. [CrossRef]

13. Loganathan, N.; Poulos, H.G.; Xu, K.J. Ground and pile-group responses due to tunnelling. Soils Found. 2001, 41, 57-67. [CrossRef] 
14. Soomro, M.A.; Bangwar, D.K.; Soomro, M.A.; Keerio, M.A. 3D Numerical Analysis of the Effects of an Advancing Tunnel on an Existing Loaded Pile Group. Eng. Technol. Appl. Sci. Res. 2018, 8, 2520-2525. [CrossRef]

15. Huang, M.; Zhang, C.; Li, Z. A simplified analysis method for the influence of tunneling on grouped piles. Tunn. Undergr. Space Technol. 2009, 24, 410-422. [CrossRef]

16. Mroueh, H.; Shahrour, I. A full 3-D finite element analysis of tunneling-adjacent structures interaction. Comput. Geotech. 2003, 30, 245-253. [CrossRef]

17. Lee, G.T.K.; Ng, C.W.W. Effects of Advancing Open Face Tunneling on an Existing Loaded Pile. J. Geotech. Geoenviron. Eng. 2005, 131, 193-201. [CrossRef]

18. Jongpradist, P.; Kaewsri, T.; Sawatparnich, A.; Suwansawat, S.; Youwai, S.; Kongkitkul, W.; Sunitsakul, J. Development of tunneling influence zones for adjacent pile foundations by numerical analyses. Tunn. Undergr. Space Technol. 2013, 34, 96-109. [CrossRef]

19. Lueprasert, P.; Jongpradist, P.; Jongpradist, P.; Suwansawat, S. Numerical investigation of tunnel deformation due to adjacent loaded pile and pile-soil-tunnel interaction. Tunn. Undergr. Space Technol. 2017, 70, 166-181. [CrossRef]

20. Loganathan, N. An Innovative Method for Assessing Tunnelling-Induced Risks to Adjacent Structures; Parsons Brinckerhoff: New York, NY, USA, 2011.

21. Burland, J.B.; Wroth, C.P. Settlement of Buildings and Associated Damage. In Settlement of Structures; Pentech Pr.: London, UK, 1974; pp. 611-654.

22. Boscardin, M.D.; Cording, E.J. Building response to excavation-induced settlement. J. Geotech. Eng. 1989, 115, 1-21. [CrossRef]

23. Burland, J.B. Assessment of Risk of Damage to Buildings due to Tunnelling and Excavation; Imperial College of Science, Technology and Medicine: London, UK, 1995.

24. Mair, R.J.; Taylor, R.N.; Burland, J.B. Prediction of Ground Movements and Assessment of Risk of Building Damage due to Bored Tunnelling. In Proceedings of the Geotechnical aspects of Underground Construction in Soft Ground, London, UK, 15-17 April 1996; pp. 713-718.

25. Bolton, M.D.; Lu, Y.C.; Sharma, J.S. Centrifuge models of tunnel construction and compensation grouting. Geotech. Asp. Undergr. Constr. Soft Ground 1996, 15-17, 471-477.

26. Loganathan, N.; Poulos, H.G.; Stewart, D.P. Centrifuge model testing of tunnelling-induced ground and pile deformations. Geotechnique 2000, 50, 283-294. [CrossRef]

27. Franza, A.; Marshall, A.M.; Haji, T.; Abdelatif, A.O.; Carbonari, S.; Morici, M. A simplified elastic analysis of tunnel-piled structure interaction. Tunn. Undergr. Space Technol. 2017, 61, 104-121. [CrossRef]

28. Abdullah, M.H.; Taha, M.R. A review of the effects of tunneling on adjacent piles. Electron. J. Geotech. Eng. 2013, $18,2739-2762$.

29. Vakili, K.N.; Lavasan, A.A.; Schanz, T.; Datcheva, M. The Influence of the Soil Constitutive Model on the Numerical Assessment of Mechanized Tunneling. In Proceedings of the 8th European Conference on Numerical Methods in Geotechnical Engineering, Delft, The Netherlands, 18-20 June 2014; pp. 889-894.

30. Zidan, A.F.; Ramadan, O.M.O. Three dimensional numerical analysis of the effects of tunnelling near piled structures. KSCE J. Civ. Eng. 2015, 19, 917-928. [CrossRef]

31. Lee, C.J.; Jacobsz, S.W. The influence of tunnelling on adjacent piled foundations. Tunn. Undergr. Space Technol. 2006, 21, 430. [CrossRef]

32. Lee, C.J. Three-dimensional numerical analyses of the response of a single pile and pile groups to tunnelling in weak weathered rock. Tunn. Undergr. Space Technol. 2012, 32, 132-142. [CrossRef]

33. National Authority for Tunnel. "Tunnel from Attaba to Geish Shaft Monitoring Measurements", Contract N 49/Metro, Phase 1"; National Authority for Tunnel: Cairo, Eqypt, 2010; pp. 270-271.

34. Mocarthy Brothers Company. A Division of Design and Management, Consultant of Attaba Parking Garage; Mocarthy Brothers Company: Cairo, Egypt, 1984.

35. Hamza Associates. Geotechnical Investigation Report; Hamza Associates: Cairo, Egypt, 2002.

36. Ayasrah, M.; Qiu, H.; Zhang, X.; Daddow, M. Prediction of Ground Settlement Induced by Slurry Shield Tunnelling in Granular Soils. Civ. Eng. J. 2020, 6, 2273-2289. [CrossRef]

37. Hejazi, Y.; Dias, D.; Kastner, R. Impact of constitutive models on the numerical analysis of underground constructions. Acta Geotech. 2008, 3, 251-258. [CrossRef]

38. Fu, Y.; He, S.; Zhang, S.; Yang, Y. Parameter Analysis on Hardening Soil Model of Soft Soil for Foundation Pits Based on Shear Rates in Shenzhen Bay, China. Adv. Mater. Sci. Eng. 2020, 2020, 7810918. [CrossRef]

39. Surarak, C.; Likitlersuang, S.; Wanatowski, D.; Balasubramaniam, A.; Oh, E.; Guan, H. Stiffness and strength parameters for hardening soil model of soft and stiff Bangkok clays. Soils Found. 2012, 52, 682-697. [CrossRef]

40. Potts, D.M.; Zdravkovic, L.; Zdravković, L. Finite Element Analysis in Geotechnical Engineering: Application; Thomas Telford: London, UK, 2001.

41. Potts, D.M.; Addenbrooke, T.I. A structure's influence on tunnelling-induced ground movements. Proc. Inst. Civ. Eng. Geotech. Eng. 1997, 125, 109-125. [CrossRef]

42. Mašín, D.; Tamagnini, C.; Viggiani, G.; Costanzo, D. Directional response of a reconstituted fine-grained soil—Part II: Performance of different constitutive models. Int. J. Numer. Anal. Methods Geomech. 2006, 30, 1303-1336. [CrossRef]

43. Obrzud, R.F. On the use of the Hardening Soil Small Strain model in geotechnical practice. Numer. Geotech. Struct. 2010, 16, 15-32. 
44. Yang, M.; Sun, Q.; Li, W.; Ma, K. Three-dimensional finite element analysis on effects of tunnel construction on nearby pile foundation. J. Cent. South Univ. Technol. 2011, 18, 909. [CrossRef]

45. Çelik, S. Comparison of Mohr-Coulomb and Hardening Soil Models' Numerical Estimation of Ground Surface Settlement Caused by Tunneling Tünel Kazısından Dolayı Zemin Yüzeyindeki Oturmaların Mohr- Coulomb ve Pekleşen Zemin Modelleriyle Nümerik Tahminlerinin Karşlaşt. Iğdır Univ. J. Inst. Sci. Technol. 2017, 7, 95-102. [CrossRef]

46. Teo, P.L.; Wong, K.S. Application of the Hardening Soil model in deep excavation analysis. IES J. Part A Civ. Struct. Eng. 2012, 5, 152-165. [CrossRef]

47. Duncan, J.M.; Buchignani, A. An Engineering Manual for Settlement Studies; University of California: Oakland, CA, USA, 1976.

48. The Housing and Building Research Center (HBRC). ECP 202/3, Egyptian Code for Soil Mechanics-Design and Construction of Foundations. Part 3, Shallow Foundation; The Housing and Building Research Center (HBRC): Cairo, Egypt, 2005.

49. Zhao, C.Y.; Lavasan, A.A.; Barciaga, T.; Zarev, V.; Datcheva, M.; Schanz, T. Model validation and calibration via back analysis for mechanized tunnel simulations-The Western Scheldt tunnel case. Comput. Geotech. 2015, 69, 601-614. [CrossRef]

50. Mayne, P.W.; Kulhawy, F.H. K0-OCR relationships in soil. J. Geotech. Eng. 1982, 108, 851-872.

51. Cheng, C.Y.; Dasari, G.R.; Leung, C.F.; Chow, Y.K.; Rosser, H.B. 3D numerical study of tunnel-soil-pile interaction. Tunn. Undergr. Space Technol. 2004, 19, 381-382.

52. Chen, L.T.; Poulos, H.G.; Loganathan, N. Pile Responses Caused by Tunneling. J. Geotech. Geoenviron. Eng. 1999, 125, $207-215$. [CrossRef]

53. Mroueh, H.; Shahrour, I. Three-dimensional finite element analysis of the interaction between tunneling and pile foundations. Int. J. Numer. Anal. Methods Geomech. 2002, 26, 217-230. [CrossRef]

54. Lee, C.J.; Chiang, K.H. Responses of single piles to tunneling-induced soil movements in sandy ground. Can. Geotech. J. 2007, 44, $1224-1241$. 